Est Ag 52 (2017) 429-488

\title{
Para una hermenéutica vital de la Palabra: Viva lectio est vita bonorum
}

\author{
SANTIAGo DíEz BARroso \\ "Y todos cuantos vagan de ti me van \\ mil gracias refiriendo"1.
}

SUMARIO: He elegido las coordenadas, que ofrece lo que he llamado "una hermenéutica vital”, como las más adecuadas, para glosar el recuerdo del compañero-profesor D. Senén Vidal García (1941-2016). En efecto, como pocos, interpretó vital y teóricamente, siempre con maestría cercana y honda, el mensaje neotestamentario. Al alimón he querido honrar la memoria de otros entrañables maestros míos, buenos a carta cabal, que se situaron en una longitud de onda similar y que, también, vivieron lo que enseñaron, dejando en mí tan honda huella: M. Legido, J. Velicia, P. Ricoeur, J. Ladrière, A. Gesché, A. Vergote.

Palabras Clave: Biblia, hermenéutica, teología, lenguaje, psicología, semántica, testimonio, fe, vivencia, parresia.

ABSTRACT: I have chosen the coordinates, which offers what I have called "a vital hermeneutics", as the most appropriate, to gloss the memory of the companion-professor D. Senén Vidal García (1941-2016). In fact, as few others, he interpreted the New Testament message vital and theoretically, always with close and deep mastery. I want to honor the memory of other dear masters, who stood at a similar wavelength and who also lived what they taught, leaving in me such a profound impression: M. Legido, J. Velicia, P. Ricoeur, J. Ladrière, A. Geshe, A. Vergote.

\footnotetext{
${ }^{1}$ S. Juan de la Cruz, Cántico Espiritual, 7, en Vida y Obras Completas de San Juan de la Cruz, BAC, Madrid 1964, 627.
} 
KEYwORDs: Bible, hermeneutics, theology, language, psychology, semantics, testimony, faith, experience, parresia.

\section{Presentación}

\section{"A los que conmigo dicen de rodillas la Palabra”.}

Esta colaboración, con motivo del homenaje al profesor Senén Vidal (1941-2016), recientemente fallecido, que fue durante muchos años profesor de Exégesis en el Estudio Teológico Agustiniano de Valladolid es una buena ocasión para seguir reflexionando, desde la que ha estado siendo mi dedicación, sobre las relaciones entre la Hermenéutica ${ }^{3}$ y la Exégesis ${ }^{4}$, a las que dedicó prácticamente su vida Senén. En la historia del pensamiento son muchos los vestigios de reciprocidad y complicidad que han mantenido con otras ciencias5. Así lo han señalado varios documentos eclesiales. El Concilio Vaticano II hizo la síntesis y abrió nuevos camino ${ }^{6}$. Posteriormente lo desarrolló la Pontificia Comisión Bíblica, La Interpretación de la Biblia en la Iglesia, Roma, 19937. Es digna de tenerse en cuenta la apertura de este documento, después de un sabio discernimiento, a todas las aportaciones de las ciencias, especialmente humanas pero también a los carismas dentro y fuera de la Iglesia, para aprovechar

2 CASAldáliga, P., Todavía estas palabras, 1994, dedicatoria.

3 "La disciplina que se ocupa clásicamente de comprender los textos" (GADAMER, H.G., "La reconstrucción y la integración como tareas hermenéuticas", en Verdad y Método, Fundamentos de una hermenéutica filosófica, Sígueme, Salamanca 1977, 217).

4 Schillebeeckx, E., "Revelación, Escritura, Tradición y Magisterio", en Revelación y Teología, Sígueme, Salamanca, 1969; RaHner, Karl, 'Historia de la Salvación y de la Revelación', en Curso Fundamental sobre la Fe, Herder, Barcelona 2003, 172-213; "La Escritura como libro de la Iglesia", en ibid., 427-436.

5 P. Ricoeur pone, como preámbulo a un ensayo suyo sobre la hermenéutica bíblica, estas palabras: "Como no soy exégeta ni un teólogo, voy a intentar aportar una contribución a la discusión adaptada a mi competencia relativa al campo de la filosofía del lenguaje” ('Paul Ricoeur et l'herméneutique biblique' en Ricoeur, Paul, L'herméneutique biblique, Cerf, Paris 2001, 147. En lo sucesivo citaremos esta obra como Hb seguido de la página; SCHILlEBEECKX, E., "Hacia una utilización católica de la hermenéutica", en Dios futuro del hombre, Sígueme, Salamanca 1970; LEvinAs, E., 'La révélation dans la tradition juive', en Varios, La Révélation, 55-77.

${ }^{6}$ DV 12.

7 Citaré como PCB seguida del párrafo correspondiente y la página en la edición española que he manejado: Pontificia Comisión BíBlica, La interpretación de la Biblia en la Iglesia, Madrid, PPC, 1994. 
la luz, que pudieran brindarle a la interpretación eclesial de la Biblia. Juan Pablo II también se ocupó de ello ${ }^{8}$. Después Benedicto XVI en la exhortación apostólica postsinodal Verbum Domini, $(2010)^{9}$, que habla de una 'sinfonía de la Palabra' basada en la analogía10. La propia Conferencia Episcopal Española ${ }^{11}$ con la Instrucción Pastoral La Sagrada Escritura en la vida de la Iglesia (2008), también se ha ocupado del tema.

Junto a la vertiente teórica también he explorado la vivencial. Ya es antigua la convicción de que los santos han hecho vida propia la Palabra y de que, por ello, son intérpretes privilegiados de la misma ${ }^{12}$. También los pobres, los pequeños, no sólo son destinatarios del evangelio sino evangelizadores, porque a ellos les revela el Padre sus secretos13: "Por su existencia, por su mirada y su palabra se nos descifra con singular claridad la gracia irrastreable del Señor, que se esconde en el misterio de la Iglesia"14. Hay, sin embargo, un estadio previo a interpretar, la realidad, y en la realidad, la vida, sobre todo la vida humana, ${ }^{15}$ que, al sedimentar las experiencias, las textifica y, por ello, se convierte en lectio, que es susceptible de testificar, de ser interpretada y ejemplarizar. Hermenéutica vital. Esta es la razón de por qué, junto a Senén Vidal, recordaré a personas, que han sido un referente para mí en algún momento de mi vida y que han hecho de la interpretación de la Palabra y del discernimiento un modo de estar en el mundo y de vivir la fe: Marcelino Legido (19352016), José Velicia (1931-1997), Paul Ricoeur (1913-2005), Jean Ladrière (1922-2008), Adolphe Gesché (1928-2003), Anton Vergote (1921-2013).

\footnotetext{
${ }^{8}$ Entre otros lugares, en la Constitución apostólica Scripturarum thesaurus (25.4.1979).

9 'La hermenéutica de la Sagrada Escritura' en Verbum Domini (2010) 29-49. Allí aparece claramente, por ejemplo, que la Iglesia es el 'lugar originario de la hermenéutica de la Biblia' (29-30); que debe seguirse lo dicho por el Concilio Vaticano II (DV 12) sobre la hermenéutica (34); que los santos, al interpretar la Escritura, abren la puerta a una 'hermenéutica vital' y de la experiencia (48-49).

La lectura del texto de la exhortación no debería dispensar de acudir a los respectivos documentos del Sínodo de 2008 sobre la Palabra de Dios, porque hay muchas reflexiones y matices sobre el tema que tratamos, que no han sido recogidas por la exhortación.

10 Verbum Domini, 7. Problema muy viejo pero recurrente, casi una puerta giratoria, cuando se trata del modo de hablar acerca de Dios. MACQUARRIE, John, "Analogía y paradoja", en God-talk, Sígueme, Salamanca 1967, 255. Mondin, B., "El método de la analogía”, en Cómo hablar de Dios hoy, Ediciones Paulinas, Madrid 1984, 161-200.

11 Conferencia Episcopal Española, Instrucción Pastoral La Sagrada Escritura en la vida de la Iglesia (7.3.2008).

12 Verbum Domini 48-49; CEC 94; “Viva lectio est vita bonorum' (S. GREGORIO Magno, Moralia in Job, 24,8,16, PL,76,295).

13 Mt 11,25.

14 Legido, Marcelino, Luz de los pueblos, Sígueme, Salamanca 1993, 11.

15 Merleau-Ponty, M., "Le corps comme expression et parole", en La Phénoménoligie de la perception, Gallimard, Paris 1945, 203-232.
} 


\section{Por el CAMino del COMPrender: Exégesis - Hermenéutica - Tra- DUCCIÓN \\ “ ¿Y cómo voy a entenderlo, si nadie me guía?16}

La Exégesis bíblica, como dice P. Ricoeur, es el nombre de un oficio, de una disciplina que se ocupa de la literatura bíblica. En torno a él se dan cita una serie de métodos, entre los que cabe distinguir, junto a la filología, el histórico-crítico ${ }^{17}$, semiológico ${ }^{18}$ y hermenéutico ${ }^{19}$. Cada uno de ellos pone a su disposición una serie de herramientas, que le ayudan a clarificar su objeto. La interpretación como tarea del pensamiento es una tarea muy antigua y compleja ${ }^{20}$. La ciencia que se ha ocupado tradicionalmente de ella es la hermenéutica. La interpretación de la Biblia puede ser considerada como una parcela en el interior de ese vasto dominio. Como práctica sistemática parece remontarse al s. XVI21, pero ya se da en el propio texto bíblico: "El problema de la interpretación de la Biblia no es una invención moderna, como a veces se querría hacer creer. La Biblia misma testimonia que su interpretación presenta dificultades" 22 . Además, la hermenéutica es absolutamente necesaria, es connatural a la propia realidad y no puede darse por concluida nunca. Hay varias razones para ello. Por un lado, como $\mathrm{X}$. Zubiri afirma, la realidad como tal-especialmente la vida humana-por el hecho de ser, de existir, tiene sentido y necesita ser interpretada. Realidad y hermenéutica remiten, pues, la una a la otra en modo de copertenencia necesitante: "Todo en la vida tiene un sentido determinado por la figura de la vida. Su aprehensión es objeto de interpretación, de hermenéutica. Hay así una lógica hermenéutica distinta de la lógica clásica.

\footnotetext{
$16 \mathrm{He} 8,31$.

17 Ricoeur, Paul, "El método histórico-crítico: sus 'aporías' filosóficas”, en Exégesis y hermenéutica, Cristiandad, Madrid 1976, 34-35.

18 Ibid., 35-44.

19 Ibid., 44-47.

20 Son de obligada referencia: Platón, Teeteto 209 A; Aristóteles, Peri Hermeneias; Dilthey, W., Die Entstehung der Hermenutik, 1909; GADAMER, H.G., Verdad y Método. Fundamentos de una hermenéutica filosófica, Salamanca, Sígueme, 1977; RICOEur, Paul, "Hermenéutique et critique des ideologies", en CASTElLI, E. (ed.), Il problema della destimitizzazione, Roma 1961; TAYLOR, Ch., "Interpretation and the Sciences of Man”, en Review of Metaphisics 25 (1971) 3-51; CORETH, E., Grundfragen der Hermeneutik. Ein philosophischer Beitrag, Herder, Friburg 1969; Grondin, J., Der Sinn für Hermeneutik, Wiss.Buchges, Darmstadt 1994.

${ }^{21}$ M. Flacius Illyricus, Clavis Scripturae Sacrae, 1567; SchleIERMACHER, F., Hermeneutik, 1838. ción, A.

22 Pontificia Comisión Bíblica, 'La Interpretación de la Biblia en la Iglesia', Introduc-
} 
Esta se refiere a 'cosas'; aquella a 'sentidos' (...). Ciertamente todo en la vida, y la vida misma, posee sentido (...). El problema no es el sentido de la realidad sino la realidad del sentido como momento real de la vida real. La vida humana es tal que tiene que tener sentido por lo que es"23. Hay, por tanto, como dijésemos, una dimensión ontológica en la interpretación y de ella participa el ser humano en cuanto realidad específica. Aunque pudiera parecer un abuso de lenguaje, deberíamos concluir que vivir, que ser, es interpretar y ser interpretado 24 . Lo cual aboca a una tarea ininterrumpida, porque vivir, estar en el mundo, precisa situarse, haberse: "Partiendo de la vida como unidad de sentido nos vemos remitidos más allá del sentido a la realidad personal que da sentido a la vida (...) La vida como conjunto de lo que el hombre hace remite a la vida como unidad interna de ese hacer, y esta unidad del hacer nos remite a su fundamento interno, al viviente mismo de quien es vida la vida" 25 .

Otra razón es que siempre se puede aspirar a comprender ${ }^{26}$ mejor el texto bíblico, porque pretende ser perennemente pertinente y concernir. Se trata de una palabra 'viva', pero antigua ${ }^{27}$, que debe ser elocuente para las diferentes generaciones a lo largo del tiempo ${ }^{28}$, que han de confrontarse con él, para hallar respuesta a los múltiples desafíos, que les plantea su historia personal y la realidad en la coyuntura concreta en que viven $^{29}$. De ahí el incesante trabajo de la traducción, sobre todo con la 'palabra viva', que es la Biblia, que pide ser expresada en la 'lengua viva' de cada generación de destinatarios.

Ninguna traducción, es cierto, puede pretender la exactitud ni agotar las posibilidades de sentido30. "Ni siquiera la traducción más esmerada

23 ZubIRI, Xavier, Sobre el hombre, Alianza, Madrid 1986, 206; OrTIZ-OsÉs, A., Antropología hermenéutica: Para una filosofía del lenguaje del hombre actual, Anthropos, Barcelona 1986.

${ }^{24}$ Sabido es que M. Heidegger ha insistido en la dimensión ontológica de la hermenéutica, aunque en una dirección bien distinta que la de X. Zubiri.

25 ZuBIRI, Sobre el hombre, 548.

26 Ricoeur, Paul, "Expliquer et comprendre. Sur quelques connexions remarquables entre la théorie du texte, la théorie de l'action et la théorie de l'histoire", en Revue Philosophique de Louvain 75 (1977) 126-147.

27 "Por lo pronto, para llegar hasta los hechos y las palabras de los cuales habla la Biblia, los lectores deben volver atrás veinte o treinta siglos, lo que no deja de suscitar dificultades" (PCB, Introducción, A).

28 GADAMER, "La historicidad de la comprensión como principio hermenéutico", en Verdad y Método, 331-377.

29 Juan Pablo II, Discurso sobre la interpretación de la Biblia en la Iglesia 30-4-1993; Id., Scripturarum Thesaurus (25.4.1979); El Documento de la PCB es decisivo para esto.

30 BAKer, M. (ed.), Routledge Encyclopedia of Translation Studies, Routledge, New York - London 2001; Gentzler, E., Contemporary Translation Theories, Routledge, Lon- 
puede sustituir a la interpretación: pertenece a la estructura de la revelación el que la Palabra de Dios sea leída en la comunidad interpretativa de la Iglesia, y que la fidelidad y la actualización estén enlazadas recíprocamente" 31 . En esta formulación echo de menos que se diga expresamente que la interpretación pertenece, primero, a la estructura de la revelación en su fase constituyente de creación de la Palabra de $\operatorname{Dios}^{32}$, de objetivación, por supuesto realizada en el seno de la Iglesia, y que luego seguirá siendo, por ello, el lugar primigenio de su interpretación ${ }^{33}$, que garantiza su recreación, su actualización ${ }^{34}$, por ser Palabra viva y eficaz. Sólo se nombra esta segunda fase y se la reduce, casi, a una mera función de 'aggionarmento', cuando en realidad, esa 'comunidad interpretativa de la Iglesia, tiene capacidad para explicitar lo implícito de ese 'depósito de la fe' y mantener abierta la fuente de la Revelación y, con ello, el desarrollo del dogma ${ }^{35}$. Compatible con que el canon de las Sagradas Escrituras esté definitivamente cerrado.

Admitida, pues, la prácticamente imposible traducción completa, el reto consistirá en conseguir una aproximación asintótica lo más perfecta posible al texto y a los destinatarios. El traductor se enfrenta con la proe-

don 2001; Munday, J., Introducing Translation Studies, Routledge, London - New York 2008; Pym, A., Exploring Translation Theories, Routledge, London - New York 2008; Id., Method in Translation History, Routledge, London - New York 1998/2014; House, J., Translation as Communication across Languages and Cultures, Routledge, London - New York 2015; D'Hulst, L., Essais d'histoire de la traduction. Avatars de Janus, Classiques Garnier, Paris 2014; NIDA, E., Toward a Science of Translating, EJ Brill, Leiden 1964; Lederer, M., Translation: The Interpretive Model, St. Jerome, Manchester 2003; Mounin, G., "Visions du monde et traduction", en Les Problèmes, 189-223. Tampoco en la traducción de la Biblia. La CEE reconoce que ninguna traducción, tampoco la suya, evitará el necesario recurso a los textos originales: "de este modo resultará aún más patente la riqueza insondable contenida en los libros sagrados, que ninguna traducción podrá agotar nunca del todo" (14).

${ }^{31}$ Benedicto XVI, Carta.

32 DV 19.

33 DV 11-13.

34 RAHNER, Karl, "La autointerpretación histórica es sencialmente necesaria de la experiencia transcendental sobrenatural", en Curso fundamental, 189-190. Esa 'autointerpretación' existencial abarca al ser humano en su conjunto y se aplica a su experiencia de 'oyente de la Palabra', de la autocomunicación revelante de Dios: “Aquellos hombres que en la terminología tradicional designamos como 'profetas', en cuanto portadores originarios -comisionados por Dios- de tal comunicación reveladora, han de concebirse como hombres en los que acontece en acción y palabra la autointerpretación de la experiencia trascendental sobrenatural de su historia” (194-195).

35 RAHNER, Karl, "Evolución de los dogmas", en Diccionario Teológico, Herder, Barcelona 1966, col. 187-190. 
za de ensamblar, con palabras, mentalidades y escalas de valores, a veces muy dispares ${ }^{36}$. Son las reglas de juego: el resultado nunca será un texto igual sino equivalente. Quien se embarca en este periplo ha de respetar con la misma fidelidad el 'mundo del texto', como lo llama P.Ricoeur, de partida y de llegada, a los diversos interlocutores, para que se logre el diálogo en las mejores condiciones, para que la traducción acierte con el significado adecuado y para que se haga justicia al autor y al destinatario. Es tan importante mantener asidos los dos cabos que, de lo contrario, desfigura el contenido o se enroca en un narcisismo estéril convirtiendo el texto para instruir y celebrar en pretexto para ritualizar, aleccionar y coleccionar. Creo que es lo que puede suceder en las traducciones de la Biblia y del Misal, por ejemplo, que por el prurito casi escrupuloso de salvaguardar la ortodoxia y la tradición se aspire a respetar el sentido original del texto y se deje un poco de lado a los 'fieles'37. Evitar este hiato es lo que movió, seguramente, a S.Vidal a realizar la traducción del Nuevo Testamento vertiendo en ella sus grandes conocimientos exegéticos, acompasándola con los últimos descubrimientos de las ciencias, con la firme voluntad de presentar un texto 'elocuente' para el hombre de hoy ${ }^{38}$. ¿Lo ha conseguido? ¿Acerca realmente un texto tan antiguo y tan 'otro' al lector de hoy, hasta el punto de empatizar con él y hacerlo suyo? Sinceramente pienso que no, que adolece de lo mismo que las demás traducciones. La lectura de la Palabra de Dios tiene que enganchar, provocar gusto por zambullirse en ella, recibirla como una verdadera carta de la familia, del mejor de los amigos, del Amigo. Entonces provocará asiduidad en la lectura y ésta garantizará su 'crecimiento'39, aprovechamiento personal ${ }^{40} \mathrm{y}$ estímulo para su estudio ${ }^{41}$.

La Pontificia Comisión Bíblica y Verbum Domini ${ }^{42}$ valoran muy positivamente la pluralidad de métodos que hay para estudiar la Biblia, advirtiendo del peligro real en dejarse condicionar por prejuicios ideoló-

\footnotetext{
36 Mounin, "Civilizations multiples", 249-270.

37 Por si hubiera alguna duda: "“no se dirigen en primer lugar a reflejar las disposiciones internas de los fieles, sino a expresar unas verdades que superan las fronteras del tiempo y del lugar" (Instrucción Liturgiam authenticam (2001), 19); en el mismo sentido se expresa la carta de Benedicto XVI (2012) dando prioridad a la ortodoxia sobre la ortopraxis; lo corrobora entre nosotros la CEE al presentar su traducción oficial Sagrada Biblia, así como la reciente traducción del Misal Romano.

38 Mondin, Cómo hablar de Dios hoy; AAVV, El lenguaje de la Fe en la Escritura y en el mundo actual, Sígueme, Salamanca, 1974.

39 S. Gregorio Magno, Homilía sobre Ezequiel 1,7-8, PL 76, 843 D.

40 DV 8.

41 CEC 94; GS 62,7; 44,2; DV 23, 24; UR 4.

42 Verbum Domini 29-49.
} 
gicos ${ }^{43}$, que distorsionan el trabajo imponiendo puntos de vista ajenos al 'mundo del texto' bíblico. Entre esos métodos aprecia la aportación de las 'hermenéuticas filosóficas' a la exégesis ${ }^{44}$. La Comisión, además de la hermenéutica, también alude a otras ciencias, que pueden serle útil a la exégesis. Tal es el caso de la lingüística con su aportación de análisis literario: retórico, narrativo, semiótico ${ }^{45}$. Pero también la sociología ${ }^{46}$, la antropología cultural, la psicología, el psicoanálisis, la teología de la liberación ${ }^{47}$, la hermenéutica feminista ${ }^{48}$.

\section{Y la Palabra se hizo texto: Biblia y Encarnación}

\section{"Y la Palabra se hizo carne" (...) Yo soy el Alfa y la Omega"}

En realidad, el hecho de que la Palabra se objetive, ya sea en textos o en vida que se vuelve texto, es una consecuencia del misterio de la Encarnación tal como se ha puesto de manifiesto en diversos documentos eclesiales sobre la Sagrada Escritura. Por ejemplo, Pío XII en su encíclica Divino Afflante Spiritu (1943) dice lo siguiente: "Al igual que la palabra sustancial de Dios se hizo semejante a los hombres en todo, excepto en el pecado, así las palabras de Dios expresadas en lenguas humanas, se han hecho en todo semejantes al lenguaje humano excepto en el error"51. Según esto, parece que la humanidad, la humanización, del

\footnotetext{
43 Ibid., 35.

44 PCB II A), 71. Cita explícitamente a R. Bultmann, H.G. Gadamer, P. Ricoeur.

45 PCB I B), 39-48.

46 "Los textos religiosos están ligados con relaciones recíprocas a las sociedades en las que nacen" (PCB I E). Theissen, Gerd, Sociología del movimiento de Jesús, Sal Terrae, Santander 1979; Id., El movimiento de Jesús. Historia social de una revolución de valores, Sígueme, Salamanca, 2005; Id., La sombra del Galileo. Un relato sobre las investigaciones históricas sobre Jesús de Nazaret, Sígueme, Salamanca ${ }^{13} 2011$.

47 Según la PCB "se busca una lectura que nace de la situación vivida por el pueblo (...) la exégesis no puede ser neutra, sino que siguiendo a Dios, debe tomar parte por los pobres y comprometerse en el combate por la liberación de los oprimidos" (PCB I, E).

48 Introduce preguntas nuevas, nuevos descubrimientos: "la sensibilidad femenina lleva a entrever y corregir ciertas intrpretaciones corrientes tendenciosas, que intentaban justificar la dominación del varón sobre la mujer (...) la exégesis feminista suscita frecuentemente cuestiones de poder en la Iglesia"; pero no debe olvidar que para Jesús el poder es servicio (PCB I D, E).

49 Jn 1,14; Lc 10,20; Lc 4,17-21; Ap 15,15: Ez 3,1-3. 2 Cor 3,3.

50 Ap 22,13.

51 Enchiridion Biblicum, 559; "La palabra de Dios, expresada en lenguas humanas, se hace semejante al lenguaje humano, como la Palabra del eterno Padre, asumiendo nuestra débil condición humana, se hizo semejante a los hombres" (Dei Verbum,13).
} 
Verbo es el paradigma de la objetivación, de la textificación ${ }^{52}$, de este lenguaje, lo cual nos invita a reflexionar sobre ese modo de llevarlo a cabo, para descubrir cómo se hace realidad concreta el lenguaje bíblico. Por otro lado, parece que lo único que preocupa en ese lenguaje, a quienes tienen la misión de interpretarlo oficialmente, es constatar su veracidad, que se da por conseguida y sobre la que no se cierne ni una sombra de duda; también parece que su adaptación y legibilidad preocupan menos o nada. En ningún caso se plantea la posibilidad de un proceso histórico, de un devenir, de un tomarse en serio que la Palabra de Dios es viva y eficaz. Juan Pablo II, relacionando Escritura y Encarnación, añade: "Es verdad que la puesta por escrito de las palabras de Dios, gracias al carisma de la inspiración escriturística, fue un primer paso hacia la encarnación del Verbo de Dios"53. Aquí sí, se habla de 'primer paso'. El cardenal J. Ratzinger en el Prefacio al documento de la Pontificia Comisión Bíblica abunda en estas ideas: "Tal estudio no está nunca completamente concluido: cada época tendrá que buscar nuevamente, a su modo, la comprensión de los libros sagrados" 54 .

Por su parte, Benedicto XVI en su exhortación apostólica Verbum Domini, habla de 'Cristología de la Palabra de Dios', de su encarnación, sacramentalidad $^{55}$, realismo ${ }^{56}$ y presenta la articulación de esa Palabra en todas sus fases: desde el seno de la Santísima Trinidad hasta la Parusía ${ }^{57}$. E. Schillebeeckx afirma que también puede serlo, en ciertas circunstancias, la palabra humana: "Cuando Pablo llama a la 'palabra de Dios' 'mi palabra', quiere significar que lo que dice el apóstol es igualmente una palabra de Cristo por medio del apóstol (1 Tes 1,5; 1 Cor 2,4 comparar con Rom 2,16; 2 Cor 4,3)"58. K. Rahner ha llamado a la Escritura "el libro de la Iglesia"59,

52 Con este neologismo nombro al proceso por el que la(s) Palabra/palabras devienen texto, escritura, rasgo y gesto, que remiten a un cierto proceso 'grammatológico' (véase J. Derrida), a una palabra ancestral (véase LEROI-GouRHAN, Le geste et la parole).

53 Discurso de Juan Pablo II sobre la interpretación de la Biblia en la Iglesia (30-4-1993).

54 Cf en Pontificia Comisión Bíblica, La interpretación, 23.

55 Verbum Domini 56.

56 Verbum Domini 10. La Palabra de Dios como fundamento de la realidad y la existencia humana (Mt 7,24).

57 Cf Benedicto XVI, Verbum Domini, Cristología de la Palabra, n. 11-13. Sabido es cómo estructura la exhortación en tres partes: 1. Verbum Dei; 2. Verbum in Ecclesia; 3. Verbum Mundo. Habla de la hermenéutica al final de la Primera Parte (29-49).

58 SCHILlebeECKX, E., "La palabra en la predicación de la Iglesia", en Revelación y Teología, 49.

59 RAHner, Karl, 'La Escritura como libro de la Iglesia', en Curso Fundamental sobre la Fe. Introducción al concepto de Cristianismo, Herder, Barcelona 2003, 427-436. 
porque en ella ha objetivado su experiencia y de ella saca los principios de su fundamentación, despliegue y misión. La Escritura se encarna en la Iglesia ad instar, según el modelo, de la Encarnación del Verbo. Considera que el misterio de la Encarnación del Verbo arraiga en el de la autocomunicación de Dios60: "La automanifestación inmanente de Dios en su plenitud eterna es la condición de la propia manifestación de Dios hacia fuera, de modo que la segunda manifestación revela la primera en una identidad"61. Dios diseña previamente, y de forma constituyente, la gramática de su posible decir: "Dios proyecta creadoramente a la criatura siempre como la gramática de un posible decir-de-sí-mismo. Y aun cuando se callara no podría proyectarla de otro modo. Porque incluso este callarse-a-sí-mismo supone siempre oídos que oigan la mudez de Dios"62. Comprobamos que la cuestión dogmática sobre la Encarnación condiciona los planteamientos lingüísticos, exegéticos y hermenéuticos. También los pastorales, porque obliga a tomarse en serio que el hombre tiene mucho que decir sobre Dios-que-se-dice-en hombre y por eso la Palabra de Dios es -parafraseando a R.Garaudy-Palabra de hombre ${ }^{63}$. No sólo, es cierto, pero muy principalmente.

\section{IV. ¿UNA 'HERMENÉUTICA VITAL'?}

\section{"La vida no es la que uno vivió, sino la que uno recuerda y cómo la recuerda para contarla" 64 .}

Es decir, una hermenéutica de la vida y para la vida que se nos ha contado y que contamos. Tomar a la vida por texto, hacerlo en su contexto, para descubrir en ella el sentido que la pone en pie y que la espolea a

60 “La palabra 'comunicación de Dios mismo' (autocomunicación) quiere significar que Dios en su realidad más auténtica se hace el constitutivo más íntimo del hombre. Se trata, pues, de una autocomunicación 'ontológica' de Dios" (RAHner, K., Curso Fundamental sobre la fe, Herder, Barcelona 2003, 147-148); "autocomunicación significa que lo comunicado es Dios en su propio ser" (ibid., 149); Dios se comunica a sí mismo como sí mismo a lo no divino sin dejar de ser lo que es (ibid., 151).

${ }^{61}$ Ibid., 265.

62 Ibid., 142.

63 Garaudy, R., Palabra de hombre, Cuadernos para el diálogo, Madrid 1977, que propugnaba, según O. GONZÁLEZ DE CARDEDAL, "un cristianismo con el hombre como centro supremo" (La Teología en España 1959-2009, Encuentro, Madrid 2011, 80).

${ }^{64}$ MÁrquez, G.G ${ }^{\mathrm{a}}$, Vivir para contarla, Mondadori, Barcelona 2002. 
seguir andando, discurriendo y narrando ${ }^{65}$. Tal ha sido, según parece, la historia del pensamiento ${ }^{66}$. Tal es la Biblia ${ }^{67}$ para mí en su conjunto, una 'sinfonía de interpretaciones', como le gusta decir a P. Ricoeur; una 'sinfonía de la Palabra' es la Revelación, como dice Benedicto XVI68. Esa urdimbre de vidas - a veces desvividas- macladas con el proyecto salvador de Dios, gracias a la presencia esencial e ineludible de la Palabra revelante 69 , que las enhebra y al Espíritu, su primer y principal intérprete. Benedicto XVI cierra, como con broche de oro, los párrafos que le dedica a la "Hermenéutica de la Sagrada Escritura en la Iglesia" en Verbum Domini70 precisamente con "Los santos y la interpretación de la Escritura"71. Los santos han vivido la Biblia y se han mirado en ella, han confrontado con ella su vida y la vida, porque de ella, como de la vida de los profetas, se sirve la Palabra para mostrarse: "En relación con la Palabra de Dios, la santidad se inscribe así, en cierto modo, en la tradición profética, en la que la Palabra de Dios toma a su servicio la vida misma del

65 Macintyre, A., Tras la virtud, Barcelona 1987, 253-271; Ricoeur, P., "La identidad personal y la identidad narrativa", en Sí mismo como otro, Siglo XXI, Madrid 1996, 106-137; "El sí y la identidad narrativa”, en IBID., 138-172. 1991, 109.

66 STEINER, G., Presencias reales. ¿Hay algo en lo que decimos?, Destino, Barcelona

67 SChILlebeEckx, E., "Revelación, Escritura, Tradición y Magisterio", en Idem, Revelación y Teología, 13-32; Ricoeur, P., "Herméneutique de l'idée de Révélation", en Varios, La Révélation, Bruxelles, Facultés Universitaires Saint-Louis, 1984, 15-54; LEVINAS, Emmanuel, "La Révélation dans la tradition juive", Ibid., 55-77; GefFré, Cl., "Esquisse d'une théologie de la révélation", ibid., 171-205. Ricoeur, P., "Sobre la exégesis de Génesis 1,1-2,4b”, en Varios, Exégesis y Hermenéutica, 59-74; Id., "À l'écoute des paraboles: Une fois de plus etonnés", en L'herméneutique biblique, Cerf, Paris 2001, 256265; Id., "Celui qui perd sa vie la trouvera", ibid., 266-272; Id., "Du langage, du symbole et de l'interprétation", en De l'interprétation. Essai sur Freud, Seuil, Paris 1965, 13-28; id., "Le conflit des interprétations", ibid., 29-44; id., "Méthode herméneutique et philosophie réflexive", ibid., 45-63; id, "La paternité: du phantasme au symbole", en CASTELLI, E. (ed.), L'Analyse du langage théologique. Le nom de Dieu, Aubier, Paris, 1969; id., "El mito 'adámico' y la visión 'escatológica' de la historia", en Finitud y culpabilidad, Taurus, Madrid 1969, 543-607.

68 Benedicto XVI, Verbum Domini, 7. Marcelino Legido prefiere hablar, por ejemplo, de 'un relato de relatos': "Pasa igual, que cuando un padre, ya mayor, se sienta a la mesa y empieza a contar la historia de su vida. Son muchas escenas, son muchas palabras" (LegIDO, M., Misericordia entrañable, Salamanca 1987, 45). La Biblia, pues, que se lee en casa, es un relato de relatos, una historia primero vivida, luego contada, finalmente escrita, para ser vivida...contada...escrita....

${ }^{69}$ Cf. los capítulos: "Relación entre la historia general de la revelación trascendental y la historia categorial especial de la revelación"; "Estructura de la historia fáctica de la revelación"; "Resumen del concepto de revelación", en RAHnER, Curso Fundamental, 188-213.

70 Ibid., 29-49.

71 Ibid., $48-49$. 
profeta. En este sentido, la santidad en la Iglesia representa una hermenéutica de la Escritura de la que nadie ya puede prescindir"72. Esa mirada privilegiada, que tienen los que han hecho vida propia la Palabra, se convierte por ello en 'locus theologicus', en hontanar de sentido, y sus vidas en texto ${ }^{73}$, en realidades dehiscentes en las que emerge la Verdad y en las que el lenguaje se corporeiza y aposenta. Están llamadas a ser, por ello, lugares de peregrinación y de encuentro.

La Biblia también es vida, es palabra viva, libre, liberadora y generadora de libertad ${ }^{74}$ palabra que muestra el camino al hablar y al vivir ${ }^{75}$, que impele y compromete a vivir como se habla y a hablar como se vive. Encarnación, compromiso y don. Dios ha dado su Palabra. Ha dicho todo lo que tenía que decir, se ha vaciado, ya no le queda más Palabra que las palabras de los hombres -por ello sólo y siempre ecolalias-, que sólo son palabras en cuanto que son exégesis y traducción de la Palabra única y definitiva. La Biblia es La-Palabra-dada-por-Dios, textificada, ratificada, testificada ${ }^{76}$. La Biblia como 'el libro de los recuerdos' de los encuentros/desencuentros entre Dios y su pueblo, que constituyen la trama de su historia vivida ${ }^{77}$, como constituyen la mía mis vivencias, ese palimsepsto de escrituras superpuestas ${ }^{78}$.

El lenguaje de la Biblia es lenguaje-para-el-camino, porque toda la historia, y especialmente la Historia de la Salvación, es 'éxodo' hacia un futuro siempre mejorable; la tierra prometida, provisional o definitiva, es retorno a Dios: "Estos textos hablan el lenguaje de la liberación y de la vuelta al futuro de Dios"79. Gracias a la proclamación, y sobre todo a la encarnación ${ }^{80}$-en la palabra y en la vida de los que hacen vida la Palabra- la Biblia texto "se dirige a ...", se convierte en palabra viva, en reve-

72 Ibid., 49.

73 Nota 12.

74 Moltmann, J., "El lenguaje de la liberación y el lenguaje liberador", en El lenguaje de la liberación, Sígueme, Salamanca 1972, 167-185.

75 "El hablar cristiano se aprende del lenguaje de la Biblia" (Ibid., 168).

76 Entre nosotros el decir: 'te doy mi palabra', equivale a: 'te me doy', 'avalo con mi persona y con mi vida lo que te digo', 'me entrego como prenda, como rehén y garantía de cumplimiento de mi acción'. Blas de Otero lo enfatiza en 'Me queda la palabra'.

77 Levinas, E.,"La révélation" 55-77.

78 Mi familia, mis amigos, mis conocidos, mis profesores, las personas con las que me encontré a lo largo de mi vida, así Senén y los arriba mencionados, son el trasunto, como en sordina, de mi biografía, de mi yo, de lo que tengo y soy, son las escrituras fehacientes, que me acreditan en mi propiedad ¡Encarnación es todo mi universo!

79 Moltmann, "El lenguaje de la liberación", 169; también "La razón del callar acerca de Dios y del hablar de Dios y hablar a Dios", ibid., 77-98.

80 Benedicto XVI, Verbum Domini, nn 32,44,55. 
lación, en manifestación de otro mundo y de otro modo de vivir en este mundo nuestro, como proponen P. Ricoeur, E.Levinas y J.Ladrière entre tantos otros.

\title{
1. Senén Vidal o el intrépido intérprete
}

\author{
"Él les dijo: 'Pues bien, un escriba \\ que se ha hecho discípulo del Reino \\ de los cielos es como un padre de familia \\ que va sacando de su tesoro lo \\ nuevo y lo antiguo" "81.
}

Porque su ojo avizor le hacía desentrañar las sucesivas capas de sedimentación, de sinfonía de voces, que un escrito pudiera tener, y porque su pulso era certero al sopesar hipótesis de trabajo y llegar a conclusiones, siempre provisionales, como es lógico en todo intelectual que se precie de serlo. Porque regresaba una y otra vez al manantial como cangilón de noria.

De Senén Vidal, su amigo y compañero X. Pikaza ha dado una magnífica semblanza en su blog titulada "Memoria de luz, una vida al servicio de la Biblia". Entre otras cosas dice: "Ha muerto esta mañana (11.4.16), mientras venía de celebrar la eucaristía, sentado en el parque de San Francisco (Salamanca), ya cerca de su casa, lleno de vida, rebosante de conocimiento y amor a la Iglesia (...) era hombre de una sola palabra, recto hasta el límite, fiel hasta la entraña". Pero también hombre de una sola palabra, la Palabra ${ }^{82}$. Precisamente de esta Palabra-en-sus-palabras hablaré ahora.

La calidad del magisterio de Senén -yo no fui alumno suyo, únicamente compañero en la docencia- se hace patente en los testimonios de quienes lo siguieron de más cerca. Transmitía, según dicen, mucho entusiasmo y pasión, gusto por la Biblia. Por mi parte, doy fe de la calidad de sus escritos hasta donde alcanzo, de la fuerza y armazón argumentativa que transmitía en sus comunicaciones habladas, de su discreción y de su saber estar. Nunca lo vi acelerado, con prisa, pareciera en todo momento que era aquello, lo que hacía entonces, su cometido y nada más. A Senén,

81 Mt 13,32.

82 Dice Pikaza X., que fueron tres los centros de interés de Senén: la literatura paulina, el evangelio y las cartas de Juan, la vida de Jesús. 
en las distancias cortas se le traslucía rumia intelectual. Esa condición de trabajador manual, que tuvo Pablo y consideró esencial para su misión, la admiraba Senén y procuraba imitarla en su dedicación investigadora. Pienso que puede servir para pergeñar su propia semblanza lo que decía de él: "En todo caso, la práctica de su oficio artesanal le sirvió enormemente a Pablo en su misión ya que con ese trabajo se ganaba el alojamiento y el sustento para él y para sus compañeros (...) le aseguraba una relación continua con la gente que acudía a la tienda donde trabajaba (...) no empleaba ciertamente la estrategia del influjo desde arriba, desde los estamentos del poder, sino la del contacto inmediato con la gente humilde" 83 . Senén también 'tejía' la trama de los textos bíblicos con los suyos. El perfil más verosímil en Pablo, de Tarso a Roma, es el de trabajador a tiempo parcial -que se diría hoy-al servicio del evangelio de Jesús el Galileo. Aquí, glosándolo a él, quiero traer el de Senén-el-Leonés-deValladolid-a-Salamanca.

Una somera mirada a la bibliografía de Senén Vidal ${ }^{84}$-particularmente especializada en S. Pablo pero que no se circunscribe a él- mues-

83 Vidal, Senén, Pablo. De Tarso a Roma, Sal Terrae, Santander 2008, 31.

${ }^{84} \mathrm{He}$ aquí algunos de sus escritos: La resurrección de los muertos: el testimonio bíblico, Sal Terrae, Santander 2015; Hechos de los Apóstoles y orígenes cristianos, Sal Terrae, Santander 2015. De esta obra dice X.Pikaza: "Se trata de una obra clave en el panorama de los estudios bíblicos en lengua castellana, una obra de autoridad en la interpretación de los orígenes cristianos" (X.Pikaza, 1.c.); Nuevo Testamento, Sal Terrae, Santander 2014. Para X. Pikaza, se trataría de una obra-síntesis de toda una vida dedicada a la investigación bíblica: "Ésta es, sin duda, una obra cumbre de la exégesis y teología hispana de los últimos decenios, posiblemente la más significativa de los últimos decenios. Estamos ante una obra cumbre: En plena madurez creadora, recogiendo y condensando trabajos anteriores, Senén Vidal ha publicado unas de las obras más importantes de la teología y vida cristiana de los últimos tiempos. Nadie, que yo sepa, ha realizado una traducción y comentario semejante de todo el Nuevo Testamento. Sólo Senén Vidal, después de más de treinta años de preparación, ha podido realizar una obra de esta envergadura: Una traducción propia del Nuevo Testamento, con introducción de conjunto y notas exegéticas de todos los libros” (1.c.,); Iniciación a Jesús de Nazaret, Sal Terrae, Santander 2014; Evangelio y cartas de Juan: génesis de los textos juánicos, Bilbao, Mensajero, 2013; Colosenses y Efesios, Verbo Divino, Estella, 2013; Las cartas auténticas de Pablo, Mensajero, Bilbao 2012; El Documento Q: los primeros dichos de Jesús, Sal Terrae, Santander 2011; Iniciación a Pablo, Sal Terrae, Santander 2008; Pablo: De Tarso a Roma, Sal Terrae, Santander 2007; El primer escrito cristiano: texto bilingüe de I Tesalonicenses con introducción y comentario, Sígueme, Salamanca 2006; Jesús el Galileo, Sal Terrae, Santander 2006; Los proyectos mesiánicos de Pablo, Sígueme, Salamanca 2005; Los tres proyectos de Jesús y el cristianismo naciente: ensayo de reconstrucción histórica, Sígueme, Salamanca 2003; Los escritos originales de la comunidad del discípulo 'amigo' de Jesús: el evangelio y las cartas de Juan, Sígueme, Salamanca 1997; Las cartas originales de Pablo, Trotta, Madrid 1996; La vida según el espíritu: reflexiones desde las cartas de Pablo, SM, Madrid, 1994; La resurrección de Jesús en las cartas de Pablo: análisis de las tradiciones, Sígueme, Salamanca 1982; Tradi- 
tra un trabajo intelectual, que toma una y otra vez los mismos asuntos y los va desgranando, sacando a flor de suelo como arcaduz de noria en manantial, pero con un mecanismo casi dialéctico: asume, profundiza, corrige y propone de nuevo con más bibliografía, más análisis, más hermenéutica... para seguir buscando. Por ello no duda en abordar a nuevas expensas un tema, que otros dejarían de lado por ya suficientemente abordado, como lo es la historia de Jesús de Nazaret o la vida y escritos del propio Pablo. Senén, por el contrario, es capaz de llevar a cabo, sin ruborizarse lo más mínimo, un 'tour de force', una proeza, y se planta en la escena editorial y académica con un tema, que a muchos les resultará manido y poco significativo, Jesús el Galileo (2006). Para justificar su osadía, casi insolencia, dice: "La nueva perspectiva que aquí se abre descubre en el acontecer histórico de la misión de Jesús un auténtico 'proceso evolutivo""85. Por eso emprende la tarea de contar de nuevo su historia.

Para Senén el apóstol Pablo constituye todo un universo, a cuyo estudio dedicó la mayor parte de su vida de investigador. Al destinarle un librosíntesis con motivo del aniversario de su nacimiento, Iniciación a Pablo (2008), dice que la misión de Jesús es la fuente de inspiración de la vida y obra de Pablo ${ }^{86}$, de su misión. Senén se refiere a ella como su 'proyecto mesiánico' en íntima conexión con el 'proyecto mesiánico' de Jesús ${ }^{87}$. Para abordar el tema dice que prefiere practicar una cierta 'inferencia'88. No optar por un análisis detallado y puntual de motivos aislados sino por la consideración de 'conjuntos estructurales amplios' en el marco que los rodea ${ }^{89}$. Si tal es la importancia de la misión de Pablo, comprenderla introduce en el corazón mismo de la del propio Jesús. Por eso cree descubrir en él, en sus escritos, una verdadera cantera y una llave maestra insustituible para franquear la puerta de aproximación a la comprensión del entramado de todo el Nuevo Testamento con fundada garantía de conseguirlo. ¿Cómo es, entonces, el evangelio de Jesús, que Pablo ha transmitido? Para averiguarlo no es recomendable hacerlo siguiendo pautas de análisis ideológico, ni si-

ciones sobre la resurrección de Jesús en las cartas de Pablo, Universidad Pontificia, Facultad de Teología, Salamanca 1979; "El amor en las cartas de Pablo", en Cauriensia 2 (2007) 157-178. Otros muchos artículos y textos de conferencias existen pero no son anotados aquí.

85 VIDAL, Jesús el Galileo, 9.

86 VIDAL, Iniciación a Pablo, 9.

87 A las 'misiones' de uno y otro Senén dedica sendas obras: Los tres proyectos de Jesús y El proyecto mesiánico de Pablo.

88 VIDAL, El proyecto mesiánico, 9.

${ }^{89}$ Ibid., 12-13. 
quiera dogmático, sino mirando al proyecto global de Jesús, con quien Pablo está en inextricable sintonía ${ }^{90}$ y que reflejó en sus textos.

De ahí su interés prioritario por explorarlos porque es en ellos, en un estudio exhaustivo y comprensivo de los mismos, donde cabe hallar lo que se pueda concluir sobre la doctrina en cuestión ${ }^{91}$. Allí aparece que Pablo, según Senén, vive lo que predica y predica lo que vive; que no parece escribir para la posteridad, sino para sus comunidades, que él pensaba que durarían hasta la parusía. Por ello no hace planes para sus escritos más allá de su utilización concreta e inmediata92. No son brindis al sol sino respuestas y propuestas para las comunidades de cristianos, que se estaban formando en aquellos momentos y en aquellos lugares. De lo cual se deduce, como dice Senén, que sus cartas constituyen la "auténtica herencia de Pablo y de su misión", a las que hay que recurrir para saber de su persona y de su enseñanza. Un análisis detallado del contenido de las cartas, como por ejemplo la dirigida a la comunidad de Roma, parece imprescindible para desentrañar el sentido de lo que allí se cuenta93. Por tanto, junto con el conocimiento del momento preciso de la misión de Pablo y las circunstancias concretas vividas por los destinatarios, resulta necesario adentrarse en el relato del texto. En el caso de la carta que estamos comentando, los materiales reunidos para su elaboración y su origen hacen plausibles ciertas conclusiones, como la de que es una especie de tratado apologético, que tiene una dimensión ecuménica y un cierto carácter de testamento: "La carta se puede considerar, efectivamente, como una recopilación de la reflexión fundamental de Pablo y de su 'escuela""94. Con lo cual se desvanece la imagen, que a veces tenemos de un Pablo, de que escribe las cartas de su puño y letra y cuenta en ellas lo que piensa personalmente y sus planes pastorales. Por el contrario, gran parte del contenido de las mismas tiene tras de sí un trabajo comunitario y coral, dejando para el redactor contarlo a su manera. Lo mismo sucedió con los relatos sobre los dichos y hechos de Jesús, como por ejemplo los de su muerte, dice Senén: "El cristianismo naciente configuró, ya desde muy temprano, una amplia tradición para expresar el sentido salvador de la muerte del mesías" (sic) ${ }^{95}$. Esta forma de proceder revela que en el proceso de formación de los textos bíblicos interviene ya una hermenéu-

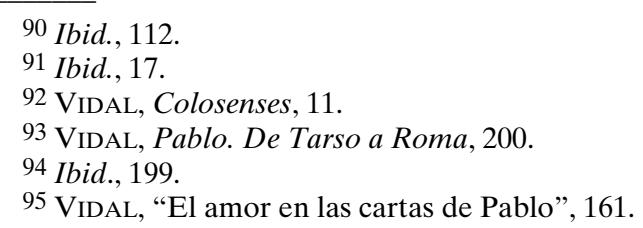


tica que selecciona, funde, amplía, interpreta aquello que luego plasmará en su conducta. Las respuestas, que da a las situaciones de sus comunidades, siendo coyunturales, continúan teniendo vigencia para la posteridad, porque se apoyan en lo esencial de la identidad cristiana y quieren recrearla.

Hay un problema de crítica textual que aborda, para determinar la credibilidad, que esos escritos merecen. Dice con resolución al respecto: "Ninguna de las cartas de Pablo se conserva como él la redactó, bien al escribirla directamente de su puño y letra, como en algún caso, o bien al dictarla a un amanuense, como normalmente sucedía. Es imprescindible, entonces, echar una mirada al proceso de transmisión de las cartas paulinas y, en especial, a los condicionantes en él implicados" 96 . A la hora de conocer los mecanismos de esa transmisión Senén avanza como hipótesis que "fueron los dirigentes de estas comunidades los que recopilaron las cartas de su fundador en una colección para el uso doméstico de las comunidades y también los que alargaron esa colección con algunas notas de comentario e incluso con nuevos escritos en forma de carta, para actualizar así, acomodándola a la nueva situación, la tradición del gran maestro de la primera generación" 97 . Es evidente que la ascendencia de Pablo es el gran fundamento en que se apoyan sus cartas. De ahí que a su sombra, con las más variadas intenciones, se cobijasen otros escritos, que recibieron el beneficio de un uso generalizado y de ser considerados canónicos. Comenzaron leyéndose en contextos litúrgicos por la comunidad a la que iban dirigidas, después copiadas, compartidas e intercambiadas con otras comunidades de discípulos. Poco a poco iban adquiriendo el valor añadido de la universalidad y se hacían susceptibles de un uso en cualquier momento y lugar, primeros pasos hacia la universalización. Tras la muerte de Pablo fueron recopiladas y coleccionadas en una 'edición ecuménica' para todas las comunidades paulinas. Algunas, posiblemente, fueron fundidas 98 en una sola para conseguir el número simbólico de siete. La transformación que sufrieron las cartas paulinas durante el primer periodo prueba que su contenido no fue preservado como un amuleto mágico sino considerado 'palabra viva'. En una aproximación minuciosa se constatan una serie de anomalías, -como saltos, rupturas,

96 Ibid., 11-12. La cursiva es mía.

97 VIDAL, "La colección de escritos paulinos", en Iniciación a Pablo, 93. La cursiva es mía para argumentar a favor de la opinión que estamos exponiendo aquí.

98 Parece, según Senén, que es el caso de 1 Corintios, resultado final de la fusión de dos cartas originales; 2 Corintios ( $=4$ cartas originales); Filipenses ( $=2$ cartas originales); Romanos ( $=2$ cartas originales). 
repeticiones, glosas, añadiduras que denotan el no haber sido redactadas por la misma mano y en idénticas circunstancias. Esto le lleva a Senén a hablar de la existencia de una cierta 'escuela' en torno a Pablo99. Principalmente en Corinto y Éfeso.

Una característica de las cartas paulinas, según Senén, es que son 'reales', dirigidas a comunidades existentes, que condicionaban su contenido y aportaban el frescor de los aspectos concretos de la vida de los componentes de esas comunidades y detalles biográficos del propio Pablo ${ }^{100}$. Su primer escrito, 1 Tesalonicenses, es auroral, conserva la tensión escatológica, que caracteriza a estos momentos de la comunidad cristiana: el Señor está a punto de regresar ¿merece la pena que nos ocupemos en algo más que lo inmediato?; si el final está próximo ¿para qué esforzarse en trabajar? También conserva la frescura de la respuesta inmediata y puntual a una situación concreta. Aún no aparecen ni las polémicas ni los desarrollos doctrinales de los escritos posteriores, cuando la vida de la comunidad se iba haciendo más compleja. Tampoco transparenta que Pablo pensase en una utilización posterior por otras comunidades ${ }^{101}$.

Igualmente se ha ocupado Senén de otros documentos del NT como los Escritos de la comunidad del discípulo 'amigo' de Jesús ${ }^{102}$. Al presentar su trabajo nos da alguna de las claves exegéticas y hermenéuticas -la importancia del texto- que ha practicado aquí en concreto, pero que son extensibles a otros de sus trabajos. ¡Sabio y audaz ejercicio de hermenéutica vital! Dice Senén que su atención "se ha centrado en lo que realmente es decisivo, en una investigación sobre documentos antiguos: en los 'textos' ahí, con toda su potencia retadora (...) ya una primera lectura elemental de ellos provoca un cierto malestar, al descubrir numerosos saltos, suturas y tensiones (...) lo cual conduce a la cuestión sobre el 'suelo' que dio asiento y sustento a esos escritos"103. Su aportación específica en el panorama general se caracteriza, según él, por ofrecer un "análisis minucioso e imaginativo de cada uno de los detalles y de las líneas configuradoras de los textos". Sus pesquisas se han materializado en unos resultados, que desean permanecer al nivel de hipótesis de trabajo abiertas a las de otros investigadores y a las suyas propias posteriores.

\footnotetext{
99 Ibid., 55.

100 VIDAL, El primer escrito cristiano, 16.

101 Ibid., 19.

102 VIDAL, Los escritos originales de la Comunidad del discípulo 'amigo' de Jesús.

103 Ibid., 9. El Sitz im Leben, que dice la crítica histórica, o lo que M. Legido llama 'puesto en la vida'.
} 
Aclarando la pertinencia de su modo de hacer vuelve a dar otra clave preciosa de su práctica exegética y hermenéutica: "Pero cada vez se hace más firme la convicción de que únicamente un análisis así puede acercar a una comprensión adecuada de los testimonios del cristianismo antiguo conservados dentro de la colección actual de escritos del nuevo testamento"104. Señalo que dice 'acercar', porque es consciente de que el proceso de la comprensión es asintótico. Por ello la tarea es ardua para distinguir a unos de otros y asignarles la credibilidad que les corresponda.

A veces la interpretación 'interesada tradicional' se ha visto corregida por la crítica, por simplista y por no conformarse con la realidad histórica, en la que se inscribe la realidad de que hablan los textos ${ }^{105}$. Por ejemplo, los análisis aplicados permiten descubrir que los escritos finales que han llegado hasta nosotros son el resultado de un complejo y 'largo proceso de formación', que han sufrido una serie de condicionantes sociales y religiosos a lo largo de su evolución, hasta convertirse en lo que hoy son. En concreto, y por lo que concierne a los escritos de Juan, se puede hablar de que existe una 'etapa fundacional', la que gesta el cañamazo a partir del cual se va elaborando el texto, en el que, según Senén, se pueden identificar los siguientes elementos: 1) Tradiciones básicas (TB); 2) Primer evangelio (E1); 3) Evangelio transformado (E2); 4) Evangelio glosado (E3); 4) La evolución posterior del evangelio (E4). Los escritos juánicos, evangelio y cartas, ha sido objeto de una doble edición por parte de Senén. Según él, no se trata de una reedición, porque hay nuevos puntos de vista, más información. Lo cual justifica evidentemente que tratándose del mismo contenido lleven título diferente106. Prueba de su inquietud investigadora y de la insatisfacción ante los resultados obtenidos que espolean a continuar buscando: "Y aunque los resultados no alcanzan nunca, por supuesto, el grado de certeza, estoy convencido de que una investigación genética de este tipo es absolutamente imprescindible para comprender adecuadamente los escritos juánicos, al igual que el resto de los escritos del Nuevo Testamento"107. La tarea del hermeneuta y del exegeta no consiste en brizar los textos, a veces hay que enfrentarse con ellos a brazo partido, despertarlos, hostigarlos, expri-

104 Ibid., 10.

105 VIDAL, Escritos joánico, 14.

106 Vidal, Los escritos originales de la comunidad del discípulo 'amigo' de Jesús; Id., Evangelio y cartas de Juan.

107 Ibid., 5.

108 VidAL, Las cartas auténticas de Pablo, 7. 
mirlos, descuartizarlos, luchar con ellos. Refiriéndose a sus trabajos sobre Pablo habla de "mi pelea con los poderosos textos paulinos" 108.

En su última obra publicada, Hechos de los apóstoles (2015), vuelve a mostrar, como lo hace una y otra vez, que el estudio de un escrito particular no puede prescindir del contexto de su formación ni del que le vincula a otros escritos neotestamentarios 109 . De esta obra, que bien debiera ser considerada como su 'testamento', porque hay mucho de Jesús y de Pablo en ella, dice: "Hechos es un documento 'imprescindible' para la construcción histórica de la vida Pablo"110. Lo cual nos remite, como en feedback cinematográfico, al comienzo de su vocación pauliana. Algo que comenzó formalmente hacia los años ochenta cuando, escribiendo sobre un texto paulino (Flp 2,6-11), precisamente en 1981, ya intuía la complejidad del camino que emprendía para el que le habían de hacer falta muchos arrestos: "la divergencia de opiniones sobre este texto paulino ha podido provocar una cierta 'desesperanza' exegética, pero lo que no ha provocado ciertamente ha sido una 'parálisis' intelectual: la moderna bibliografía sobre él es ya casi inabarcable"111. Lo cual a él no le arredraba. Ya en esos primeros momentos valoraba la utilidad que cabía esperar de la hermenéutica para lo que pretendía: "El presente estudio no quiere entrar de nuevo en la intrincada maraña de discusión y análisis de las varias hipótesis y cuestiones de detalle. Lo que intenta, mas bien, es abrir un camino a la comprensión global del texto: ensaya fijar el lugar teológico, dentro del cristianismo primitivo, del canto o himno tradicional que sin duda, conforme a la demostración y parecer común de la exégesis actual, Pablo aquí cita"112. Sus análisis le llevan a la conclusión de que se encontraba frente ana pieza literaria rara pero interesante: un himno litúrgico muy antiguo, en el que ha cristalizado, junto a la devoción y exaltación del sacrificio de Jesús en la cruz, una reivindicación: “...el canto de Flp 2,6-11 hay que localizarlo en la primitiva polémica sobre la cruz de las comunidades cristianas pre-paulinas, que vivían en un medio helenista"113. Los interlocutores no serían judíos, que veían en la cruz una maldición de Dios y de la ley, sino helenistas anti-cristianos, que ven esa forma de muerte como 'mors turpissima crucis', 'servitutis extremum sum-

\footnotetext{
109 VIDAL, Hechos de los Apóstoles y orígenes cristianos, Sal Terrae, Santander 2015, 9.

110 Ibid., 160. También dice que es "como una apología o defensa del movimiento cristiano de su tiempo" (l.c.,).

111 Vidal, "Fpl 2,6-11: Su lugar teológico". Es una separata de un artículo publicado en Quaere Paulum, Salamanca, 1981, 149 (para el artículo completo 149-161).

112 Ibid., 149-150. El subrayado es mío.

113 Ibid., 160.

114 En ese caso, Flp 2,6-11, estaría muy próximo a I Cor 1-2.
} 
mumque supplicium'. El himno, pues, les habría servido para explicar esa 'locura de la cruz'114. Pablo lo toma de un contexto litúrgico judeo-helenista: "El texto hay que fijarlo en el culto de las comunidades judeo-helenistas, que fueron sin lugar a duda, las más decisivas en la configuración del cristianismo primitivo" 115 . Me interesa subrayar el hecho de que a través de estas 'incorporaciones' aparece, según Senén, cómo el cañamazo de la Escritura se iba formando con la incorporación de piezas de experiencias con localizaciones y contextos muy diversos, con finalidades -culto, apologética, didascalia- diferentes: "El canto habría sido un poderoso instrumento cristiano, el más antiguo que conocemos, de justificación de la fe cristológica, explicando esa locura de la cruz"116. El texto se muestra, pues, como catalizador y aglutinante de la fe vivida, objetivada, textificada y testificada. Con lo cual Senén abría la puerta a la necesaria colaboración con otras metodologías científicas. Algo que la PCB pediría diez años más tarde en el documento que profusamente hemos comentado más arriba.

Este estudio temprano en la producción académica de Senén denota ya el interés paulino, que le iba a acompañar toda su vida. Lo que afirma de las cartas de Pablo bien puede ampliarse a todo el conjunto de los escritos bíblicos. Nacidas de un afán evangelizador se fueron acomodando a las circunstancias concretas de los destinatarios mediante una múltiple operación hermenéutica que seguía un movimiento inductivo /deductivo: de la vida a los textos y de éstos nuevamente a la vida por un proceso inverso y complementario. Obrando así, bajo la supervisión de los apóstoles, cada comunidad se arrogaba el derecho, en buena lógica, de añadir, quitar o adaptar con arreglo a sus necesidades y a su manera de comprender lo que se les contaba. Son la Iglesia en su función constituyente de 'comunidad interpretativa'. Como dice Senén, no había nada de raro en esa práctica, era natural que así fuera: "No es de extrañar que este lento proceso de formación de la colección de escritos paulinos implicara una profunda transformación de las cartas originales de Pablo. Se trataba de una evolución natural en una tradición viva, como lo eran las cartas de Pablo, ya que seguían utilizándose en las comunidades paulinas y necesitaban, entonces, una continua interpretación y actualización, para poder acomodarse a las nuevas situaciones"117. Es así cómo se iba componiendo el corpus escriturario en la etapa constituyente de la Revelación y de la Escritura. Es lo que constata

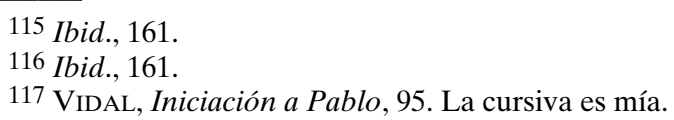


Senén, como otros exegetas, con los dichos de Jesús, cuando tomaba pasajes del A.T. En realidad la acomodación era el peaje que debían pagar para mostrar que se 'cumplían' - 'esta Escritura, que acabáis de oír, se ha cumplido hoy' (Lc 4,21)- como Escritura revelada. La novedad era el anclaje que se le daba a un texto, proclamado 'in illo tempore', para que iluminase y diera sentido a una circunstancia a primera vista diferente de aquella para la que fue dicho entonces. Luego los apóstoles, aprendiendo lo que habían oido y visto hacer a Jesús, lo imitaron y lo practicaron ${ }^{118}$. Para un autor como Lucas, por ejemplo, 'contar a Jesucristo' lleva consigo "seguir las huellas de su presencia en la comunidad que apela a él"119. Lo cual significa que la Palabra se hace texto en sus vidas antes que en su predicación y sus escritos. Creo que esta forma de proceder no es exclusiva de Lucas ni del género narrativo, sino que es aplicable a toda la génesis de la Escritura como tal en su conjunto: "Entonces me dijo: 'Hijo de hombre, come lo que tienes ahí; cómete este volumen y vete a hablar a la casa de Israel" 120. Ley del ministerio apostólico: Cree lo que lees. Enseña lo que crees. Practica lo que enseñas. Contribuye a que se ponga por escrito y pueda ser leído también por otros...

Por tanto es imprescindible, creo, reconocer la función constituyente de la comunidad - guiada por el Espíritu y supervisada por el Magisterio - cuyo trabajo, a veces, no concluyó en la confección de un escrito acabado, pormenorizado, estructurado y concluyente, sino en una mera colección de fragmentos, o de 'Dichos de Jesús', como fue el Documento Q "que quiso ser simplemente una recopilación de dichos de Jesús, con la finalidad de servir de instrucción con autoridad para los grupos cristianos"121. Dichos fragmentarios, "transmitidos oralmente, probablemente en arameo"122, de muy diverso tipo, de talante sapiencial y profético principalmente: "Ese amplio y variado material de dichos se iría conjuntando poco a poco en pequeñas agrupaciones para la memorización, con vistas a facilitar su uso comunitario"123, que la comunidad no se limitaba a 'recibir' sino también a 'trans-

118 AletTI, Jean-Noël, "Contar a Jesucristo", en El arte de contar a Jesucristo. Lectura narrativa del evangelio de Lucas, Sígueme, Salamanca 1992, 175-190.

119 Ibid., 190.

$120 \mathrm{Ez} 3,1$.

121 VIDAL, El documento $Q, 17$.

122 Ibid., 19.

123 Ibid., 19.

124 Mt 5,21-48; 7,15-16.21-27; 11,29-30; Lc 1,38. 46-56; 2,10-12.17-19.28.33.51; 7,22; Jn 1,14.27-41; 8,38-43.46; 17,7-8.14.20.26; He 1,21-22; 1 Cor 2,1-5;11,23; 1 Cor 15, 1-8; Gál 2,20; Ef 3,2-5; 4,20-21; 5,1-2; Flp 2,5; 3,1;1Tim 1,15; 4,11;6,4; 2Tim 2,2; 4,1-2; Sant 3,1-12. 13-18; 1 Pe 3,15-16;1Jn 1, 1-4; Ap.2,14-15;3,8.19-20;5,1ss. 
mitir'124. Los estratos del texto original muestran su origen y los esfuerzos de adaptación y síntesis. Este proceso de elaboración no era singular sino común a otros muchos textos bíblicos: "Eso no representaba nada extraño, en absoluto, dentro de una tradición viva, como era la de Q, que, aun después de recopilarse en un escrito, debía seguir actualizándose y creciendo, conforme a las necesidades de las comunidades"125. Leer los dichos de Jesús en el contexto socio-cultural y religioso en que fueron pronunciados garantiza el que se les comprenda según el sentido con que fueron proferidos, y pone al abrigo de interpretaciones sesgadas y gratuitas o interesadas. Por ejemplo, esos 'dichos' deben ser contextualizados conforme a la misión tanto de Jesús como de sus primeros discípulos, también de Pablo. Opina Senén que las conclusiones, que se saquen de ellos, dependen del tratamiento que se les preste, pudiendo dar origen a 'interpretaciones distorsionadas', si no es el correcto126. Lo exige una hermenéutica que se precie de eclesial y de científica, como la que ha procurado practicar él, respetuosa con los textos y con los destinatarios, mostrando su amor a la Iglesia desde la discreción pero con firmeza insobornable, consciente de que ese era el mejor servicio, que les podía prestar a los potenciales oyentes de la Palabra.

Una de las características que honran a Senén Vidal es el haber sido un exegeta 'todo-terreno'. Con la experiencia acumulada a lo largo de los años, y en continuidad con sus análisis y comentarios a la literatura paulina, entre los que se cuentan traducciones parciales de alguno de sus escritos $^{127}$, se atreve a emprender una tarea colosal, traducir al español y comentar todo el Nuevo Testamento ${ }^{128}$, que tanto alaba X. Pikaza en su semblanza ${ }^{129}$. Allí también muestra algunas de las pautas que ha seguido su hermenéutica. Recuerda, por ejemplo, algo que ya sabíamos, que lo que hoy tenemos como 'texto' es el resultado de un largo y complejo proceso, en su conjunto y en cada uno de sus escritos, que abarca desde el comienzo hasta el s. IV. Se constatan, dice él, una serie de fluctuaciones y diferencias entre las diversas comunidades, en que se utilizaba para el culto y la instrucción. Valorando su trabajo de traductor, escribe: "Son bien conocidas las dificultades para la traducción de los textos antiguos,

125 Ibid., 22. Sobre este proceso de formación del NT ver CROsSAN, J.D., El nacimiento del cristianismo. Qué sucedió en los años inmediatamente posteriores a la ejecución de Jesús, Sal Terrae, Santander 2002.

126 VIDAL, El documento Q, 113.

127 VIDAL, El primer escrito cristiano.

128 VIDAL, Nuevo Testamento.

129 Cf. aquí mismo más arriba. 
ya que han surgido en una lengua y en un mundo social, cultural y simbólico muy diferentes de los nuestros. Esas dificultades se agudizan cuando, además, se trata de textos manoseados de continuo desde su origen hasta hoy, como es el caso de nuestros textos paulinos"130. Esto por lo que se refiere al término 'a quo'. Pero una traducción es mucho más, ha de tenerse no menos en cuenta a los destinatarios de la misma, como he señalado aquí mismo más arriba, el término 'ad quem'. No vale cualquier resultado sino únicamente el que haga legible el texto. Creo que, desgraciadamente, tampoco Senén sale indemne de la prueba. Su traducción es manifiestamente mejorable.

Vistas así la exégesis y la hermenéutica, tal como las contempla y practica Senén, tienen ante sí una larga y prometedora tarea, que se dilatará en el tiempo de forma ininterrumpida, porque siempre aparecerán nuevos textos y los ya aparecidos incesantemente serán susceptibles de nuevas puestas a punto para una mejor comprensión. Además, el propio desarrollo cultural las nuevas situaciones en la Iglesia y el mundo serán un reto constante para la renovación de los textos. La exégesis y la hermenéutica bíblicas se sienten espoleadas por el mordiente de ofrecer a los destinatarios de las sucesivas generaciones propuestas sugerentes que los impliquen, que los conecte. Una insatisfacción, casi obsesiva, era la que le empujaba a Senén a revisitar incesantemente los textos. La convicción de que lo dicho jamás lo es de una vez por todas y para siempre, porque se inserta ineludiblemente en una tradición viva, que por definición está, como la vida misma, en permanente proceso de adaptación y desarrollo. La dehiscencia de los escritos y el fluir de la vida les asegura a la hermenéutica y a la exégesis un feraz porvenir ${ }^{131}$. Para una travesía semejante no abundan los buenos compañeros de viaje como lo fue Senén. Sus libros nos servirán de guías y de planos.

\section{Marcelino Legido: cursiva reverente minúscula}

"Pues yo, hermanos, cuando fui a vosotros, no fui con el prestigio de la palabra o de la sabiduría a anunciaros el misterio de Dios"132.

\footnotetext{
130 VIDAL, Las cartas auténticas de Pablo, 9.

131 Algunos dicen que fatídico, al compararlo con los ascensos/descensos/ascensos... de Prometeo.

132 I Cor 2,1.
} 
A mí también se me ha muerto marcelino -parea mí escrito así como quiso ser y parecer en el curso de su vida: una 'cursiva reverente minúscu$l a$ ', pequeño entre los pequeños, manso- para las crónicas fue: Marcelino Legido López (1935-2016) ${ }^{133}$. En él tomó muy especialmente cuerpo la Palabra, testificada y textificada. Sacerdote abulense/salmantino, de vocación tardía -le gustaba decir que era discípulo de la hora undécimafallecido sólo tres meses después de Senén, y para quien Pablo de Tarso fue maestro y guía también ${ }^{134}$. Precisamente a su eclesiología dedicó una documentadísima y voluminosa ${ }^{135}$ tesis doctoral, muy en la línea que había decidido seguir y que mantuvo hasta el final: no sólo saber sino sabiduría. Marcelino era experto en practicar una exégesis narrativa, encarnada y orante, una exégesis de altísimo rigor intelectual, que no empañó su trabajo entre los emigrantes españoles en Alemania -a los que alfabetizaba en sencilla hermandad durante su confección. Mientras, otros colegas y compatriotas suyos -entonces becados en Alemania como él, hoy catedráticos y cardenales, algunos eméritos- se prodigaban en conciertos musicales y actos de sociedad en el Munich de los años sesenta. La exégesis de Legido, influida por K.Marx, pero también por Unamuno ${ }^{136}$, E. Mounier, X. Zubiri137, Ch. Foucauld ${ }^{138}$, R. Voillaume, Pablo VI, Platón ${ }^{139}$, así como por J. Jeremías, G.F. Kittel, M. Schlier, E. Käsemann, G. Eihholz, W. Schrage, J.A. Fitzmyer, P. Stuhlmacher, L. Arnaldich, M. Cordero, L. Turrado..., en íntima mimesis con Jesús el artesano

133 De él hace X. Pikaza esta sentida semblanza en su blog: "Llevaba un tiempo retirado, ha muerto consumido y consumado por el sufrimiento y la esperanza, por el amor, la penitencia y la ternura (...) Su tesis doctoral en teología se titulaba: 'La iglesia del Señor: un estudio de eclesiología paulina' (Salamanca 1978), un libro clave, imprescindible todavía”.

134 En la abundante bibliografía sobre Pablo, que Senén da en sus escritos, me sorprende no haber visto ninguna referencia a M. Legido ( $i$ ?), cuando es un significativo especialista suyo por la calidad de sus comentarios y ante la escasez de bibliografía española de alto nivel sobre el tema, sin embargo cita a otros autores de bastante menos tomo. Me ha parecido una omisión sangrante.

135 ¡198 páginas de texto +461 de notas!

136 LEgido LóPEZ, Marcelino, "El hombre de carne y hueso. (Estudio sobre la antropología de D. Miguel de Unamuno", en Unamuno a los cien años estudio y discursos salmantinos en su centenario, 1967, 29-58.

137 Legido LóPeZ, Marcelino, "La meditación sobre la esencia de X. Zubiri”, en Salmanticensis 10 (1963) 363-381.

138 Muerto en Tamanrasset, Argelia, el 1 de diciembre de 1916.

139 "Era uno de los mejores conocedores del pensamiento de Platón y de San Pablo, sobre el que escribió algunos libros ejemplares, que siguen siendo de referencia para los estudiosos”. (X. Pikaza, l.c.,). 
de Nazaret, con el tejedor Pablo de Tarso, muchos obreros, campesinos y militantes cristianos, alumbraba una teología liberadora y mística con sabor y olor a barracón de emigrantes -Gastarbeiters- y a cocina de carbón, que no a sopa de convento y primores monjiles. Luego, con gran coherencia, la encarnó en comunidades rurales empobrecidas y expoliadas, como las paulinas de entonces y los pobres campesinos ignorantes (am ha' aretz) de la Palestina de antaño. Marcelino fue un maestro en leer la realidad ${ }^{140}$ ya fuera como sacerdote rural o como flamante joven profesor de filosofía en la Salamanca de los años sesenta, en sintonía con la 'Cátedra Pablo VI'141; hermanado con Belda, Alberdi, Freijo, Setién, Ortega, Marías, Flórez; apostando por el compromiso político y social. Ya le mordía, entonces, la inquietud por la misión, por la comunicabilidad, por la comunión sobre todo a ese nivel existencial, en que la persona se constituye, al entrar en diálogo con el Tú absoluto. Para Marcelino era incuestionable la centralidad de Cristo. Así lo pensaba, así lo vivía y textificaba, así lo testificaba: “¡Cristo! Cristo, nuestro principio; Cristo, nuestra vida y nuestra guía; Cristo, nuestra esperanza y nuestro término. Él solo. Ninguna otra luz. Ninguna otra verdad. Ninguna otra aspiración. Ninguna otra esperanza. Solo él. Exclusivamente él. Totalmente él”.

Vivió piadosamente siempre ${ }^{142} \mathrm{y}$, mientras las fuerzas físicas le acompañaron, ${ }^{143}$ a pie de pueblo, de aldea-escasa-en-todo, fronteriza y esquilmada, en pobreza y obediencia, injertado en la Iglesia en Castilla, contagiando sus vivencias muy especialmente en Salamanca y entre muchos presbíteros y laicos de tantas iglesias. Tarea y preocupación compartida con Senén Vidal144. Ambos -leonés y abulense/salmantino- dejaron impronta, por senderos diferentes, en la Iglesia y muy concretamente nuestra Iglesia en Castilla. Murieron el mismo año. Es de justicia, pues, recordarlos juntos. Marcelino tenía claro, y así lo vivía y proponía, que el

\footnotetext{
140 LEGIDO, Marcelino, "Eucaristía y Justicia. Apuntes para una contemplación bíblica”, en Varios, Reflexiones militantes Cristianas II: Voz de los sin voz, Madrid 1993, 3-34.

141 Legido, Marcelino, "Persona humana y Tú absoluto", en Varios, El problema del ateísmo, Sígueme, Salamanca, 1967, 249-286; volumen que recoge los trabajos del segundo curso de la Cátedra; en el mismo volumen publican Palenzuela, Yurre, Alberdi, C. Paris, J. Marías. Otro título de la cátedra fue: Marxismo y hombre cristiano, Cátedra Pablo VI, Madrid 1966, en el que también colaboró.

142 No una piedad ñoña sino de altísima contemplación mística, como la de sus paisanos el mudejarillo Juan de la Cruz y Teresa de Ávila, pero también la de Juan de Ávila, tan preocupado por la Iglesia, como él, y formador de tantas personas, también como él.

143 Berzosa, Raúl, Homilía durante el funeral, Salamanca 2016.

144 Senén Vidal era 'operario diocesano, pertenecía a la Hermandad de Sacerdotes Operarios Diocesanos, fundada por D. Manuel Domingo y Sol (1836-1909), que tiene como carisma la formación de los aspirantes al sacerdocio.
} 
evangelio de Jesús de Nazaret, muerto y resucitado, Señor de la historia, vivía en el recuerdo y en la vida de los suyos -muy principalmente en Pablo de Tarso, decía él. Descifrarlos, para entenderlos mejor y poder vivirlos con mayor fidelidad, fue su obra. Entender el proceso de la comprensión que tuvieron de su misión siempre le pareció a Marcelino el mejor camino para comprenderlos a ellos, y la 'hermenéutica vital' la mejor de las hermenéuticas posibles ${ }^{145}$. Todo se juega, pues, en una articulación de comprensiones, a las que hay que sumar la que tiene el propio hermeneuta del texto que interpreta. Marcelino Legido es consciente de ello y dice que hay que actuar con decisión pero con parsimonia, para no desfigurarlo imponiéndole concepciones ajenas a él. No obstante la ciencia pone a su disposición estudios histórico-críticos que le facilitan la tarea, de otro modo sería poco menos que imposible poder tener acceso a un texto aparecido en un contexto muy diferente ${ }^{146}$. Marcelino explicita el principio metodológico, que aplica en su investigación concreta, pero que es extrapolable a otros contextos generales y suyos propios. Muy de acuerdo con las directivas de la PCB como hemos visto más arriba. También es consciente de que el corpus neotestamentario es constitutivamente 'fragmentario' y tiene tras de sí experiencias plurales de fe, que iluminan la marcha de los que vienen detrás como fogonazos clareadores del camino.

Muestras de buen hacer han sido sus charlas y sus Ejercicios Espirituales siempre ungidos por el halo de la Presencia, que se intuía densa, honda y familiar en él, que inducía complicidad y contagiaba anhelo de Absoluto. Consciente de la complejidad y singularidad de cada situación, exponía respetuoso la 'lógica del evangelio' y dejaba que cada cual sacara sus propias conclusiones. Ni componendas, ni paños calientes, ni dirigismos. Su exposición, densa y resuelta, fluía mansamente y solía plasmarse en cálidos dibujos que interpelaban como signos de interrogación. El vigor de su convicción, siempre al abrigo de halagos, reconocimientos y reproches, le dotaba de un pulso certero, compasivo y con candor del bueno. Su gran sentido de Iglesia le hacía obsequioso con la jerarquía, jamás adulador, siempre exigente, siempre obediente, pero irreductiblemente libre y servicial, lo mismo que con sus hermanos los sacerdotes y los laicos entre los que deseaba contar como un hermano menor, obrero de la hora undécima, contratado al atardecer. Por obediencia a su enton-

145 LEgIDO, Marcelino, "Perspectivas sobre la comprensión paulina de la historia salvífica (1893-1972)", en Salmanticensis 22 (1975) 5.

146 Ibid. 
ces obispo de Salamanca, Mauro Rubio Repullés (1919-2000), pasó a limpio unas notas de trabajo sobre Lumen gentium, para reflexionarlas en grupos $^{147}$. En ellas aparece mucho de su modo de entender y vivir el evangelio, su puesto en la Iglesia y en el mundo. Allí leemos muchas pautas de lo que vengo llamando, con P. Ricoeur, una 'hermenéutica vital'148. No lo presenta como un material de altos vuelos académicos, sino como "un trabajo sencillo" de hermenéutica -"desentrañar las líneas maestras del documento de manera honda y transparente"- que sirva para "una meditación pneumática y eucarística del misterio de la Iglesia"; para una 'catequesis mistagógica': "la contemplación del Hijo entregado y exaltado, el Hombre nuevo, absoluta gracia y entera novedad que hace germinar la nueva creación" ${ }^{149}$, siguiendo la lógica de los propios documentos conciliares. Es la perspectiva que aconsejaba adoptar el Sínodo de 1985, dedicado a una relectura del Concilio Vaticano II. Esta hermenéutica mantiene un triple punto de vista sobre la Iglesia: altura, hondura y espesura, muy paulino ${ }^{150}$, por otro lado, y muy afín con S.Juan de la Cruz ${ }^{151}$. Porque la Iglesia es una gran familia de familias que vive su fe encarnada en pequeñas comunidades, que son el epicentro de la soberanía cósmica del Señor ${ }^{152}$. La Iglesia es también "el pequeño fermento del mundo que está pasando a ser mesa compartida" 153 . Pero es otras muchas cosas: 'Reino de Cristo en misterio'154, 'tienda de campaña para la peregrinación'155, 'mesa puesta y puerta abierta'156 en medio del mundo ${ }^{157}$, que anticipa la mesa del último día ${ }^{158}$.

Estamos ante un trabajo de catequesis hermenéutica policéntrica y descentralizada: "la catequesis lee la palabra en la mesa de la Iglesia del Vaticano II. Hay como un camino de ida y vuelta. Del concilio pasamos al evangelio para acabar leyendo el concilio desde el evangelio"159. Y el

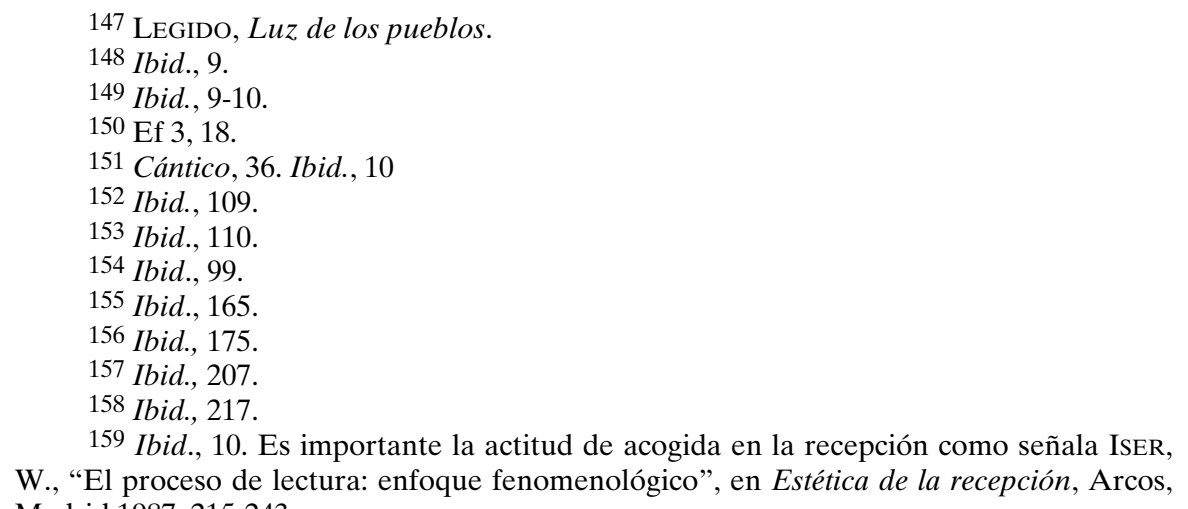


todo enhebrado por un objetivo primordial: "Pues nuestro único propósito es que pasen a la mesa de la comunidad la Escritura santa y el texto mismo del concilio (...) Que aparezcan los textos en desnudez y plenitud"160. Un trabajo solvente en el que no disminuye la exigencia técnica por mor del servicio pastoral: "la catequesis, es decir el ejercicio de lectura y de interpretación, ha de ser una contemplación pneumática y eucarística, evangélica y evangelizadora, mistagógica, no directiva ni selectiva, misionera, que inicie a la oración y a la fraternidad, comprometida: "iniciación al compromiso histórico desde la lectura de los signos de los tiempos" 161 ; que tiene en los pobres los destinatarios privilegiados; que adopta "un lenguaje al estilo de Jesús (...) que es como un relato que se cuenta o una canción que se canta". Apostando por un modo de evangelizar, narrativo y orante, que fue el de los orígenes de la Iglesia.

La expresión 'su puesto en la vida' articula el pensar de Marcelino, es una pieza clave de su hermenéutica, porque le otorga densidad y concreción a la realidad y hace justicia a la estructura misma de la reflexión, como lo muestra en uno de sus trabajos académicos: "El estudio histórico-crítico de la eclesiología paulina exige valorar y asumir toda la historia de su investigación. Pero al recorrerla se nos plantea el problema hermenéutico de su puesto en la vida" ${ }^{162}$. Al mismo tiempo, como reconocía Marcelino en un artículo sobre La Esencia de X. Zubiri, es muy importante, para conocer el pensamiento de otra persona, situarse en su punto de vista; sólo entonces sus palabras son comprendidas en su verdadero alcance: "Sólo cuando salimos de nosotros y nos situamos en el punto de vista del otro, se nos esclarecen sus palabras"163. P. Ricoeur dirá que haciéndolo a través de la objetivación de los textos y no por medio de elucubraciones adivinatorias. Igualmente sucede con el manejo de los tiempos del intérprete y del pensamiento a interpretar. Siendo imprescindible recurrir al pasado, para comprenderlo desde su interior, debe hacerse de tal modo que no se proyecten sobre él las apreciaciones del presente, porque en ese caso se velará y no se desvelará. Se practicaría, en suma, una interpretación distorsionada. Por lo cual, "tomar conciencia de esta dialéctica es posibilitar la objetividad del análisis histórico en su alcance y en su limitación"164.

160 Ibid., 10-11. La cursiva es mía.

161 Ibid., 11.

162 LEGIDO, "Las interpretaciones de la eclesiología paulina", 417.

163 LEgIDO, "La meditación sobre la esencia de X. Zubiri", en Salmanticensis 10 (1963) 363-381.

164 Ibid. 
En buena medida este ejercicio hermenéutico salva su credibilidad sin menoscabo de su eficacia, cuando la subjetividad interpretante se ejercita de forma colegial como es el caso de la comunidad cristiana cuando interpreta un texto bíblico. Entonces 'el puesto en la vida' es comunitario en ambos cabos del proceso -al constituirse y al actualizarse- y se erige en criterio determinante de discernimiento para una 'hermenéutica coral'165. Este principio hermenéutico, es evidente, se aplica a los propios 'papeles' de Marcelino, autor que se diluye en el texto y éste, a su vez en la comunidad eclesial, su verdadero autor y auténtico destinatario166. En el primero de los temas, que trata del 'misterio de la Iglesia', Marcelino propone comenzar con una parábola: "Para comprender con hondura el misterio de la Iglesia del Señor, conviene partir de una sencilla parábola de la familia en el hogar"167. Una historia que es éxodo y que se ha trenzado con el esfuerzo cruzado de muchas voluntades.

También el compromiso social le ocupó a M. Legido, aunque de un modo muy peculiar, como todo en él. En efecto, su identificación con el evangelio fue tan plena que lo religioso y lo social no estaban en sus inquietudes y reflexiones como compartimentos estancos, sino imbricados, como en implicación biunívoca: el evangelio lleva al compromiso y éste al evangelio. Se puede constatar en su comentario a la Instrucción pastoral $L a$ Iglesia en Castilla, samaritana y solidaria con los pobres (1991)168. Como al leer los documentos conciliares dio prioridad al evangelio, para que fuera el criterio y la norma para la correcta interpretación, así también lo hace aquí: "mi aportación se resume nada más que en esta palabra (es una aportación cristológica): 'Jesús, el Señor, nuestra justicia'. Nuestra justicia en la Mesa: sus manos son la mesa; nuestra justicia en el Camino: sus huellas son el camino"169. Un camino en el que la cruz se hace presente y que pide ser iluminado desde el camino que recorrió Jesús (Filp 2,6-11). A propósito de la interpretación que hace Pablo dice M. Legido: "Pablo, él y sus hermanos, ha preferido en sus escritos, en vez de contar, cantar el misterio de la cruz en los Himnos (...) Pablo y sus hermanos presentan el misterio pascual

165 LEGIDO, Luz de los pueblos, 11-12.

166 Ibid., 12.

167 Ibid., 19. Un símil recurrente que aparece muy frecuentemente en sus exposiciones y que él desarrolla con verdadera maestría narradora (Marcelino Legido, "Una casa para la familia de los hombres"), en Misericordia entrañable, Salamanca 1987, 44-62.

168 LEGIDO, Marcelino, "Eucaristía y justicia. Apuntes para una contemplación bíblica, I Parte: Del camino del evangelio a la mesa de la Pascua'; II Parte: 'De la mesa de la Pascua al camino del Evangelio", en Legido, Rovira Belloso, Ruiz de la PeÑa, Reflexiones cristianas II, Movimiento Cultural Cristiano, Madrid 1993, 3-18 y 19-34 respectivamente.

169 Ibid., 3. 
como una liturgia de entronización del Hijo del Rey (...) Y así podemos comprender ahora la comprensión de Pablo y sus hermanos, la comprensión paulina de la Justicia aparecida en la Pascua"170. De igual modo la realidad de Castilla pide ser leída a la luz del Misterio Pascual: "Así es ahora la situación histórica de Castilla. Está en la nada como nunca jamás ha estado así de hundida. Pero eso es fantástico. Porque el Cristo Pascual, crucificado y victorioso, justamente ha hecho aparecer su Gracia en el 'No-Ser'"'171. Entonces, de una situación de ruina, puede surgir un futuro alentador -o felix culpa- gracias a que, como le sucedió a Cristo, su 'descenso' hasta la aniquilación se convertirá en el punto de anclaje para su 'ascenso'. El lugar del discernimiento y de la recreación será la mesa eucarística, que se convierte, por ello, en el centro de gravedad de la Nueva Creación: En el acontecimiento de la Plegaria Eucarística sucede todo el misterio que estamos descifrando. El Señor con los brazos extendidos y abiertos delante de nosotros nos muestra su Cuerpo roto y su Sangre vertida"172. Desde esta interpretación de lo que sucede al celebrar la cena del Señor 'se comprende mejor', dice Marcelino, por qué Pablo y sus discípulos pusieron la celebración en el contexto, en que había una polémica sobre los pobres. Interpretan el sentido de lo que se celebra como camino para interpretar el lugar de los pobres en la comunidad y en el mundo. De ahí la exigencia de que se corporeice la koinonía en torno a la mesa: las divisiones que existen en la comunidad únicamente quedarán abolidas, cuando se celebre 'eficazmente' y con plenitud de sentido, la cena del Señor. Por ello la comunidad de bienes se enraíza en la eucaristía, que pasa a ser, de un mero rito, fons et origo $^{173}$, pan para el camino de la misión, por la que "libres en su libertad para servir en su servicio, entramos en la comunión de destino con Él (...) Nada de miedo, por tanto, al volver a la primera voz del evangelio (...) El Señor va delante, atrás y al lado. Él hará posible en nuestra flaqueza el abandono y la alabanza, vivido todo en el corazón de la Iglesia y del mundo"174. En esa travesía, según M. Legido, es importante acertar en el discernimiento de los signos de los tiempos ${ }^{175}$. El Espíritu, cuando es invitado como compañero de camino, garantiza la llegada y el gozoso encuentro.

\footnotetext{
170 Ibid., 16. La cursiva es mía.

171 Ibid., 17. Su bagaje filosófico le permite entroncar gracia / pecado / ser/ no-ser.. ¿Pablo en el Areópago (Hch 17,21-31)?

172 L.c., 23. El subrayado es mío.

173 Vaticano II subrayó que la liturgia es la cumbre (culmen) y la fuente (fons) de la actividad de la Iglesia (SC 10).

174 L.c., 33 .

175 Gaudium et Spes 11; González Carvajal, L., Los signos de los tiempos. El reino de Dios está entre nosotros, Sal Terrae, Santander 1987, 23-49; MERINo BEAs, P., "La
} 


\title{
3. Las 'edades' de un hombre cabal: José Velicia
}

\author{
Equívocos: "Donde tú dices ley, / yo digo Dios. / \\ Donde tú dices paz, justicia, amor, / \\ yo digo Dios! / Donde tú dices Dios, \\ lyo digo libertad, justicia y amor"176.
}

También se hace 'texto’ para mí, muy especialmente, la vida de José Velicia, sacerdote diocesano como yo. Nunca se tuvo por algo. 'Soy como el chico de los recados', me dijo un día y no era del todo así. Pero sí era un cura todo-terreno, que aunaba simplicidad franciscana con exquisitez casi refinada; duro como la escarcha y tierno como la nieve, poseía el brío del caballo de tiro junto con la torpeza del recental; capaz de sufrir y de gozar por las pequeñas cosas; humor con chispa y con retranca; diáfano y previsible. Siempre lo encontrabas dispuesto para lo que hiciera falta. A mí, por ejemplo, me acogió sin apenas conocerme y me abrió puertas, las del Estudio Teológico Agustiniano, sin ir más lejos, al presentarme a Carlos Morán y Alfonso Garrido ${ }^{177}$; pero también las del Estudio de los Dominicos en Valladolid con el entonces director P. Cándido Aniz.

José Velicia es y será recordado principalmente por ser el impulsor de las Edades del Hombre ${ }^{178}$. Pero, cuando llegaron éstas, él ya tenía otras 'edades'. Su pastoral venía de más hondo y de más lejos, de tiempos muy complicados y recios ${ }^{179}$. Testigo de ello será siempre su 'Parresa'180 -que es como se llamaba el despacho/recepción en la parroquia de S.Ildefonso, que él re-

categoría teológica 'signos de los tiempos': usos e implicancias en el magisterio y la teología católica", en Anales de Teología de la UCSC 8 (2006) 65-167; CHENU, M.D., "Les signes des temps", en Nouvelle Revue Théologique 87 (1965) 29-39.

176 Casaldáliga, P., Equívocos.

177 Siempre tan disponible y lúcido, con quien tanto aprecié. Él, como algunos otros profesores del Centro, que tanto hicieron por su puesta en marcha y funcionamiento -pienso, por ejemplo, en el P. Fidel a quien sustituí en la cátedra de Epistemología- bien hubieran merecido un 'recordatorio' como el que hoy se le hace a Senén Vidal.

178 José Jiménez Lozano fue uno de los mentores y quien escribió algunos de sus guiones; Pablo Puente, el arquitecto que diseñó los ámbitos de las exposiciones, Eloisa Watemberg la responsable del equipo de asesoramiento artístico, Ignacio de la intendencia.

179 De todos estos y otros muchos aspectos de su vida se ha dado puntual cuenta en los diversos homenajes, que se le han dedicado. Mi testimonio, sin embargo -no sé si suma o resta- es de primera mano.

180 'Parresa' remite al sustantivo 'parrhesía' y al verbo 'parrhesiasthomai'. tiene relación con el Éxodo y la Pascua, sucesos-cumbre de liberación. Términos que nombran una palabra pública, audaz, arriesgada, honesta, veraz, en libertad, para el bien común, que construye comunidad (Jesús; Mc 8.32; Jn 7,4.13.26;10,24;11,14; 16,25.29; 18,20; Apóstoles: He 2,29; 4,13.29.31; 9,27.28; 13,46; 14,3; 18,26; 19,8; 26,26; 28,31; 2Cor 3,12;7,4; Ef 3,12; 
modeló. A ella me adscribieron como diácono, recién venido de Lovaina (1975), y en ella fui ordenado presbítero, al año de llegar a Valladolid, por D.José Delicado Baeza el 12 de junio de 1976. Con José Velicia aprendías cercanía y evangelio. Por la parroquia pasaban muchos tipos de personas: grupos de trabajo para asambleas multicolor (sindicales, asociaciones de vecinos, pastorales, políticas) en tiempos de clandestinidad y de censura, aprietos y desasosiegos. Desde ella colaboró en la Asamblea Conjunta de Sacerdotes a nivel nacional y coordinó una Asamblea General Diocesana junto con A. Meléndez. En las tertulias de café, casi diario, con José Jiménez y otros amigos de ambos, a las que me asoció, se gestaron las Edades y se hablaba de política, muy candente en el otoño del setenta y cinco; pero también de cine y de literatura y de variedades; con un País fresco que daba los primeros pasos y leíamos con avidez; con una Seminci que proyectaba a Passolini y Bergman, con un Delibes en plena efervescencia, que se dejaba caer a veces los domingos por la misa de doce en S. Ildefonso.

El calado humano y religioso de Pepe Velicia no dejaba indiferente. Lo corriente en él era que siempre te sorprendía con una mayor generosidad y una más cálida acogida, cuando uno pensaba que ya había recibido de él cuanto cabía esperar. Una rara mezcla de sagacidad e ingenuidad, de llaneza y aristocracia, de candor y astucia, de ligereza y ponderación, de magnanimidad, y una finísima ironía, una flamante vespa roja, boina y pipa, un señor muy de a pie, lúcido, un todo-cura, piadoso, pastoral, bueno para tiempos recios, bueno, un hombre de Palabra.

\title{
4. Paul Ricoeur: intérprete multisectorial y hacedor de convergen- cias: una filigrana de infrecuente virtuosismo
}

\author{
"Sois carta de Cristo, \\ redactada por nuestro ministerio"181
}

\footnotetext{
6,19.20; Flp 1,20; 1 Tes 2,2; 1 Tim 3,13; Flm 8; Heb 3,6; 4,16; 10,19.35; 1 Jn 2,28; 3,21; 4,17; 5,14). FABRis, R., Le virtu del coraggio. La "franchezza" nella Biblia, Casale Monferrato 1985; 'Discourse and Truth: the Problematization of Parrhesia'. (Six lectures given by Michel Foucault at the University of California at Berkeley, Oct-Nov. 1983), editadas por J. Pearson 1999. Según este autor el término aparece por primera vez en las obras de Eurípides. Demóstenes en las Filípicas dice: "quiero decirte lo que pienso sin ocultarse nada". Los Padres utilizan frecuentemente el término. Al poner ese término en el dintel de la puerta, deseaba evidentemente que inspirase su propia vida y la de sus feligreses de la parroquia de S. Ildefonso.

1812 Cor 3,3 .
} 
Mi profesor en cursos monográficos de semántica y de hermenéutica en la Université Catholique de Louvain (UCL). Fue un hermeneuta de raza. De él ha dicho Richard Kearney: "Ricoeur was one of the most challenging, hospitable, an enduring thinkers of the twentieth Century"182. Inquieto, con muchos registros, curioso multivalente. Pretendía vivir interpretando e interpretar viviendo. Hizo de la hermenéutica fenomenológica una pasión ${ }^{183}$, concreción de su razón vital, una lógica existencial184. Estaba firmemente convencido de que "un proceso de interpretación auténtico no es sólo intelectual sino también vital", "un proceso íntimamente dramático" 185 , porque lleva a trascender la letra, pero tiene la recompensa, como en S. Agustín, de saciar con ello su sed de verdad ${ }^{186}$ y peraltar la condición humana. Huyendo, en todo momento, de practicar interpretaciones subjetivas, sesgadas, arbitrarias, y anti-eclesiales, que toman partido instrumentalizando los textos sagrados para guarecer sus propias convicciones ideológicas ${ }^{187}$. Fue un adalid en defender que el ecumenismo necesita llevar a cabo trabajos serios de colaboración en

182 "Ricoeur fue uno de los más desafiantes, acogedores y resistentes pensadores del siglo XX", Kearney, R., en Research in Phenomenology 35 (2005) 4. R. Kearney es profesor de filosofía en Boston College, especializado en filosofía de la imaginación creativa, fenomenología y hermenéutica. Ha escrito: Poétique du Possible: Vers une Herméneutique Phénoménologique de la figuration, Beauchesne, Paris 1984; Dialogues with Contemporary Continental Thinkers: The Phenomenological Heritage, Manchester University Press, Manchester 1984; Modern Movements in European Philosophy, Manchester University Press, Manchester 1987.

183 Ricoeur, P., De l'interprétation. Essai sur Freud, Seuil, Paris 1965; La conflit des interprétations. Essais d'herméneutique, Seuil, Paris, 1969; Essays on Biblical Interpretation, Fortress Press, Philadelphia 1980; Cours sur l'herméneutique, Louvain, Institut Supérieur de Philosophie, 1971-1972 (curso ciclostilado); "La Bible et l'imagination", en Revue d'histoire et de philosophie religieuse 66 (1982) 339-360; "D'un Testament à l'autre: essai d'herméneutique biblique", en Lectures 3, Paris, 1994, 355-364; "Le recit interpretatif. Exegèse et théologie dans les récits de la Passion", en Recherches de Science Religieuse 73 (1985) 17-38; "Herméneutique de l'idée de révélation", en Varios, La Révélation, Facultés Universitaires Saint-Louis, Bruxelles 1984, 15-54; "Poética y simbólica", en Iniciación a la práctica de la teología I, Cristiandad, Madrid 1984, 43-69; LACocoue, A. -Ricoeur, P., Pensar la Biblia. Estudios exegéticos y hermenéuticos, Herder, Barcelona 2001; THOMPSON, J.B., Critical Hermeneutics. A Study in the Thouhgt of Paul Ricoeur and Jürgen Habermas, University Press, Cambridge 1981; VAnHOOZER, K.J., Biblical Narrative in the Philosophy of Paul Ricoeur, Cambridge, University Press, 1990.

184 Ricoeur, P., "Logique herméneutique", en Contemporary Philosophy. A New Survey, La Haya 1981, 179-223.

185 Verbum Domini, 38. Esta 'hermenéutica vital' encaja perfectamente, es lo que pienso, con la trayectoria existencial de las personas rememoradas en la presente colaboración. Ricoeur, P., "La acción considerada como un texto", en Hennenéunca y acción, Editorial Docencia, Buenos Aires 1985.

186 Benedicto XVI, Audiencia General 9 de enero de 2008.

187 Verbum Domini, 44. 
hermenéutica bíblica pero también la universidad y el mundo de la cultura en general. De ahí su perfil intelectual polifacético y multiversal. Tuvo siempre el don de una comprensión exigente y honesta, de entrar dentro de los sistemas y posibilitar la explicitación de sus más secretos y fecundos veneros, lo mejor de sí mismos, para crear las condiciones de posibilidad de un encuentro dialogal. Era encomiable cómo, siendo de confesión evangélica sin fisuras ni titubeos, participaba indistintamente en foros católicos, agnósticos, reformados con respeto equidistante, con circunspección y con solvencia, ganada por la seriedad de sus planteamientos tan clarividentes, aglutinantes y propositivos.

Como señala O. Pöggeler, Paul Ricoeur ha hecho filosofía a partir de su encuentro con la filosofía alemana, pero luego ha dado prueba de su propio quehacer filosófico, no sólo en París y Nanterre, sino también en Lovaina, Roma, Chicago ${ }^{188}$. La suya es una fenomenología hermenéutica o una hermenéutica fenomenológica, que bebe en múltiples tradiciones filosóficas y religiosas, que se refiere a mitos, símbolos y creencias diversas, que practica una interpretación existencial de la exégesis bíblica y desenmascara críticamente ideologías de la mano de los que ha llamado 'maestros de la sospecha': Freud, Nietzsche y Marx. Frente al estructuralismo, que hacía de la fonología el modelo para todas las demás ciencias y negaba el sujeto, P.Ricoeur asume la importancia del lenguaje pero basculando su interés hacia el texto, principalmente el texto escrito, que adopta cierta autonomía respecto al autor ${ }^{189}$. En su última obra, Tiempo y relato, cuyo primer volumen apareció en 1983, intenta comprender la historia y el tiempo desde la actividad de la narración ${ }^{190}$. El propio $\mathrm{P}$. Ricoeur describe así las coordenadas de su perfil intelectual: "Yo quisiera caracterizar la tradición filosófica de la cual dependo con tres rasgos: está en la línea de una filosofía reflexiva; permanece en la esfera de influencia

188 Hegel-Preis der Landeshauptstadt Stuttgart. En esa misma ocasión, con motivo de habérsele otorgado en Stuttgart el premio Hegel a P. Ricoeur en 1985 concluía diciendo: "Paul Ricoeur ha conducido la filosofía fenomenológica a una dimensión hermenéutica, ha validado el enfoque hermenéutico en la discusión con las corrientes de crítica de la ideología y cientificistas, y, de este modo, partiendo de nuestros empeños actuales, ha creado la posibilidad de conservar, transformándolo, el legado de Hegel”. Este prestigioso premio fue otorgado en 1973 a J. Habermas; en 1979 a H.G. Gadamer; en 1982 a R. Jakobson. Instituido en 1967, se otorga cada tres años; la primera vez fue concedido en 1970 con motivo del $200^{\circ}$ aniversario del nacimiento de Georg Wilhelm Friedrich Hegel; está dotado con doce mil euros y nunca puede quedar desierto.

189 Ricoeur, P., "El método semiológico", en Varios, Exégesis y hermenéutica, 35-44.

190 Celis, R., "La dynamique du roman biblique", en Varios, Narration et Interprétation, Facultés Saint-Louis, Bruxelles 1984, 167-195; Ricoeur, P., "Le discours narratif", en Varios, La Révélation, Facultés Saint-Louis, Bruxelles 19-22. 
de la fenomenología husserliana; quiere ser una variante hermenéutica de esta fenomenología"191. A pesar de su incontestable compromiso con la fe cristiana no quiere que su pensamiento sea clasificado como 'filosofía cristiana' ${ }^{192}$. Pretende mantener asidos ambos cabos, fe y razón, sin que el uno contamine al otro. Él entiende que por el hecho de que la fe cristiana ocupe una gran parte de su esfuerzo intelectual, que nutra su pensamiento y de que se manifieste cristiano, no por ello disminuye el rigor de su análisis ni se compromete su neutralidad ${ }^{193}$. Su periplo intelectual le abocará a meterse de lleno en la hermenéutica, un campo que ya había explorado en sus primeros escritos sobre 'la simbólica del mal', para hacer frente a un 'conflicto de interpretaciones', que él resolverá en una 'convergencia' 194 siempre necesitada de ser reconstruida. En ese contexto la hermenéutica, según él, es "teoría de la interpretación", se diferencia de la exégesis: "Pretende ser la teoría de lo que es comprender en relación con la explicación de los textos en general (...) Es, pues, una teoría general del sentido en relación con una teoría general del texto que determina la amplitud de la hermenéutica en general. El problema hermenéutico existe como tal porque existen textos"195. Se puede afirmar que el acto de interpretación tiene como tres tiempos en P.Ricoeur:1) La pre-comprensión o primera mimesis que consiste en la visión del universo que aporta el lector consigo, es la pre-figuración; 2) Aproximación explicativa objetivante, es la segunda mimesis, la con-figuración del texto a explicar; 3) encuentro del 'mundo del texto' con una multitud de lecto-

191 Riceeur, P., "De l'interprétation”, en: Du texte a l'action, Essais d'herméneutique II, Seuil, Paris 1986, 25.

192 F-X. Amherdt califica su posición ante la fe cristiana como 'un christianisme de philosophe'. Otros autores defienden que hay que separar en él ambos dominios, tal es el caso de la obra Buhler, P. - Frey, D. (dir.), Paul Ricoeur: un philosophe lit la Bible. A l'entrecroisement des herméneutiques philosophique et biblique, Labor et Fides, Genève 2011; AMHerdT, F-X., L'herméneutique philosophique de Paul Ricoeur et son importance pour l'exégèse biblique. En debat avec avec la New Yale Theology School, Cerf - Saint Agustin, Paris - Fribourg 2004. El autor defiende que en P. Ricoeur se da lo que él llama un "dialogue d'inclusion mutuelle' entre la hermenéutica filosófica y bíblica.

193 Frey, D., "Paul Ricoeur, 'L’herméneutique biblique”", en Autres Temps, Cahiers d' ethique sociale et politique, 76-77 (2003) 196-197; Amherdt, F-X., "Heménetique philosophique et herméneutique biblique chez Paul Ricoeur: un dialogue fecond", en Paul Ricoeur, un humanisme en dialoque. Colloque Academique, Marseille 5-6-7-8 de junio de 2013. Citaré como Coloquio.

194 Ricoeur, P., "Del conflicto a la convergencia de los métodos en exégesis bíblica", en Varios, Exégesis y Hermenéutica, 33-50; El conflicto de las interpretaciones. Ensayos de hermenéutica, Fondo de Cultura Económica, México 2015; Freud, una interpretación de la Cultura, Siglo XXI, Madrid 1990; Pöggeler, O., "El conflicto de las interpretaciones", con motivo de la recepción del Premio Hegel por P. Ricoeur en 1985.

195 Ricoeur, "Del conflicto", 44. 
res, tercera mimesis, la re-figuración. El lector es convocado a comprender mejor lo real y a sí mismo.

Para él hay hermenéutica cuando se pone el acento sobre el 'verbo' hablado o escrito, en la transmisión histórica del texto y en la interpretación. Los 'criterios de la textualidad' se dan, cuando aparece la 'efectuación' del lenguaje como discurso y el 'distanciamiento' del texto respecto al autor, quedando a merced de la interpretación del lector: "Lo que es comunicado, más allá de la significación interna de un texto, es el mundo que proyecta y el horizonte que constituye. Recíprocamente el lector recibe esta pro-posición o pro-yecto de mundo, según su capacidad limitada de responder, que es a su vez definida según una situación que es limitada, y que a pesar de todo abre a un horizonte de mundo"196. Entonces la hermenéutica, en ese contexto, llevará a cabo un trabajo de reconstrucción a partir de la estructura misma del discurso. Por eso afirma: "Recuérdese nuestra insistencia en definir la tarea de hermenéutica no más a partir de la intención del autor, supuestamente escondida detrás del texto, sino a partir de la calidad de ser-en-el-mundo desplegado delante del texto, como la referencia de ese texto"197. Según esto, "comprender es comprenderse delante del texto"198. De este modo la hermenéutica del texto -con producciones sobre la metáfora ${ }^{199}$ y la narración ${ }^{200}$ - desemboca en una 'hermenéutica de la acción'201, que tiene por cometido global en la obra de Ricoeur elaborar una 'hermenéutica de sí', una antropología. Según Ricoeur: "No cabe duda de que no hay interpretación inocente; filósofo y teólogo son quienes interpretan en la medida en que ponen el texto en relación con una problemática instaurada en otro lugar" 202. La tarea de la hermenéutica propiamente no es ocuparse de la 'escritura' que produce un discurso inmediatamente autónomo respecto a la intención del autor; ni la 'obra', que sería la puesta en forma de lo dicho mediante el estilo, sino el 'mundo' del texto, es decir, la referencia del discurso, no 'lo que es dicho' sino 'aquello sobre lo que' es dicho:

196 'Le texte comme identité dynamique', en Hb., 143-144.

197 Ricoeur, P., "Herméneutique de l'idée de la Révélation”, en Ricoeur, P. - Lévinas, E. - Haulotte, E. (eds.), La Révélation, Publications des Facultés universitaires SaintLouis, Bruselas 1984, 46.

198 Ricoeur, P., "De l'interprétation”, en Du texte a l'action, Essais d'herméneutique II, Seuil, Paris 1986, 116-117.

199 Ricoeur, P., La metáfora viva, Trotta, Madrid 2001.

200 Ricoeur, P., Tiempo y narración, Siglo XXI, México 1995.

201 Varios, Hermenéutica y acción. Crisis de la Modernidad y nuevos caminos de la Metafísica, Junta de Castilla y León, Valladolid 1999.

202 P.Ricoeur., 'Interpretación', en Exégesis y Teología, Madrid, Cristiandad, 1976, 70. 
"la cosa del texto, he ahí el objeto de la hermenéutica. Y la cosa del texto es el mundo que el texto despliega ante él"203. Un texto, que hay que abordar sin violencias, con parsimonia, como saboreándolo ${ }^{204}$.

En el campo de la hermenéutica bíblica ha trabajado abundantemente. Resultado notorio de ello ha sido, por ejemplo, su trabajo con el exégeta A. LaCocque, en el que van estudiando una serie de textos del AT205. La interpretación que se lleva a cabo no es una "violencia inferida al texto", la simple irrupción de la subjetividad del exégeta en la objetividad del texto, sino la confrontación del texto que se interpreta con otros textos, con los que se entra en diálogo y en los que se busca apoyo para descubrir el sentido.

Y es por ahí, en la práctica de una respetuosa hermenéutica, donde P. Ricoeur se siente cómodo, al abrigo de sospechas, él que tan profundamente conoció a los 'maestros de la sospecha', y con una gran credibilidad tanto en foros católicos como protestantes, gnósticos o ateos. Debemos estarle agradecidos, porque ha prestado un gran servicio tanto al ecumenismo como al diálogo interreligioso, pero también al diálogo fe cultura o simplemente intercultural. El secreto no es otro que su respeto y sincero culto a la polifonía de la verdad que, según él, es mimesis y correlato de la Verdad. Practica la hermenéutica filosófica y bíblica en 'diálogo de inclusión mutua' teniendo como horizonte lo que él llama "la polifonía de la Escritura" y respetando fielmente la regla de "no confusión' entre ambos dominios. La intercomunicación entre ambas y al mismo tiempo su originalidad propia las describe en estos términos: "La hermenéutica bíblica es por turno una hermenéutica regional y una hermenéutica única que se adjunta la hermenéutica filosófica como su propio 'órgano'. Es un caso 'particular' en que la Biblia es uno de los grandes poemas de la existencia. Es un caso 'único', porque todos los discursos parciales están referidos al Nombre que es el punto de interpretación y la casilla vacía de todos nuestros discursos sobre Dios, en nombre del Innombrable"206. Lo específico de la hermenéutica bíblica frente a la hermenéutica filosófica ${ }^{207}$ se sitúa para él en el círculo que for-

203 Ricoeur, P., "La réponse d'une philosophie herméneutique", en Varios, La Révelation, Facultés Sain-Louis, Bruxelles 1984, 34-35.

204 Barthes, R., El Placer del texto, Siglo XXI, México 1974.

205 LaCocque, A. - Ricoeur, P., Pensar la Biblia: Estudios exegéticos y hermenéuticos, Herder, Barcelona 2009.

206 Ricoeur, P., 'L’herméneutique et l'idée de Révélation', en Varios, La Révélation., 42.

207 Ricoevr, P., "Herméneutique philosophique et herméneutique biblique", en Bovon, F. - Roulller, G. (ed.), Exegesis, Neuchâtel/Paris 1975, 216-258; "D'un Testa- 
man comunidad creyente y Escritura inspirada. Entonces, el hecho de pertenecer a la comunidad creyente y aceptar la autoridad de aquella, implica que se aceptan los textos sagrados como que provienen verdaderamente de Dios y con capacidad para que incidan en la propia vida, cuando son leídos.

\section{Jean Ladrière: un intelectual clarividente, comprometido y bonda- doso}

"Beatus vir qui timet Dominum”208

Era una paradigmática encarnación de la honradez intelectual, un dechado de sencillez y de clarividencia, la interpretación canónica del beatus vir, alabado en las Escrituras. Fue mi profesor de Filosofía de la Ciencia, Filosofía del Lenguaje, Filosofía Social en la UCL (Université Catholique de Louvain). La vida del profesor J. Ladrière (1922-2008) ${ }^{209}$ fue sencilla y frugal sin aspavientos. De profundas convicciones católicas, las vivía comprometida, discreta y respetuosamente. Habitaba en una buhardilla -le visité en ella varias veces, no le daba empacho el citarnos allí a sus alumnos-a la que se accedía por una estrecha escalera, sin ascensor, ni placa a la puerta, limpia, ordenada, acogedora, luminosa, como la celda de un monje ilustrado:

ment à l'autre. Essai d'herméneutique biblique", en MArguerat, D. -Zumstein, J. (ed.) La mémoire et le temps. Mélanges offerts à Pierre Bonnard, Généve 1991, 299-309; retomado en Lectures 3, Paris, 1994, 355-364.

208 Ps 112,1.

209 Muere un 26 de noviembre de 2007. Fue mi profesor en Lovaina entre 1971 y 1975. Estuvo tan volcado en la enseñanza y en la respuesta a las innumerables invitaciones a los foros más diversos que apenas tuvo tiempo de redactar obras sistemáticas. Se han coleccionado algunas de sus colaboraciones en obras antológicas como LADRIÈRE, J., $L a$ articulación del sentido, Sígueme, Salamanca 2001. Aquí me intereso principalmente por el Libro Segundo: Los lenguajes de la fe, 263-602. También tiene un artículo, "Le langage de la foi", en la Enciclopedia Universalis, vol.7, Paris 1980, 75-78; La foi chrétienne et le Destin de la raison, Cerf, Paris, 2004; Le temps du possible, Bibliothèque philosophique de Louvain, éd. de l'ISP - Peeters, Louvain-la-Neuve, Louvain-Paris 2004; L'espérance de la raison, Bibliothèque philosophique de Louvain, éd. de l'ISP - Peeters, Louvain-la-Neuve Louvain-Paris, 2004. Después de su muerte se ha editado una bibliografía exhaustiva de más de cien páginas: Bibliographie de Jean Ladrière. Euvres-articles-personalia, Bibliothèque philosophique de Louvain, éd. de l'ISP - Peeters, Louvain-la-Neuve - Louvain-Paris, 2005; Gentzen, Recherches sur la déduction logique (Untersuchungen über das logische Schliessen), traduction et commentaire par Robert Feys et Jean Ladrière, 1955; Les limitations internes des formalismes. Étude sur la signification du théorème de Gödel et des théorèmes apparentés dans la théorie des fondements des mathématiques, NauwelaertsGauthier-Villars, Leuven-Paris 1957 (ed. réed. éd. J. Gabay, coll "les grands classiques", Paris 1992); 'Sens et vérité en théologie', L'Articulation du sens. III, Cerf, Paris, 2004. 
libros, tesinas, tesis, apuntes, olía a limpio, como a colada recién hecha, como a heno y romero. Discreto, pulcro; caminaba con viveza y pasos cortos, la mirada recogida, aspecto frágil, ojillos vivarachos y voz cantarina, suave; cabello corto, blanco e hirsuto; vestía sencillo, colores discretos, muy frecuentemente en azul oscuro; era tímido, respetuoso, entrañable, obsequioso, finamente irónico, matizado, parco en palabras, perspicaz, valiente, solidario, animoso, tierno, vivaz, acogedor, generoso -con lo que no consumía pagaba becas a estudiantes, ayudaba a organizaciones humanitarias, adoptaba-, un cristiano de misa diaria -se decía-, pero no un 'beato', con una espiritualidad abierta y comprometida, un místico en la acción, un activista piadoso; que se hacía querer -'n'est-ce pas?', era un latiguillo frecuente en su decir que no era retórico, que denotaba un espíritu vivo, inquieto, en ebullición ininterrumpida, en proceso continuo de formación, implicativo, interpelante-, en los exámenes sufría tanto o más que el alumno, porque no quería escrutar si éste sabía o no, pillarle, sino mostrarle que sabía, ayudarle a expresare y a establecer las conexiones con otros temas del programa ofreciendo tablas de salvación; disfrutaba ostensiblemente si el alumno respondía bien -se apresuraba a decir c'es ça, eso es, con amplia sonrisa casi de niño maravillosamente sorprendido-; si era consultado sobre un tema de tesis o de tesina gozaba con las propuestas y convencía al alumno de las inmensas posibilidades que tenía su desarrollo ${ }^{210}$ y se implicaba en la búsqueda de materiales, en la lectura de borradores, prodigando y facilitando entrevistas, muchas veces en su propio domicilio. De una de ellas nos ha llegado el siguiente perfil:

Poseía la extraordinaria capacidad de maravillarse de una anécdota como de un teorema y de hacer compartir esta admiración incluso por aquellos que estaban lo menos predispuestos a hacerlo. Poseía también una facultad excepcional de escuchar atentamente a sus interlocutores, respetuosamente, generosamente, a los más modestos como a los más fanfarrones, de reformular más concretamente, a menudo con ilustraciones al apoyo, la parte fundamental de lo que intentaban expresar, a veces muy confusamente 211 .

210 Mi profesor de filosofía contemporánea en la UCL J. Taminiaux, en su testimonio tras las exequias de J. Ladrière cuenta cómo su mujer se benefició de este buen saberhacer de J. Ladrière, cuando elaboró su tesis doctoral. Pero los testimonios, en este sentido, son copiosos. Yo mismo fui asesorado con generosidad por él en mis tesinas sobre M. Blondel y J.R. Searle así como en otros trabajos.

211 Philippe Van Parijs, alumno de J. Ladrière, compañero mío en la UCL, hoy profesor de filosofía y de ética allí, también en Harward y Oxford, cofundador de la Red Europea de 
Exquisitamente disponible y cercano, un dechado de honradez total. Gran conocedor de Frege, Cantor, Gödel, Wittgenstein, Russell, Popper, Evans, Austin, Searle, Chomsky, Habermas, a quienes dedicó cursos y conferencias, y sobre quienes dirigió abundantes tesis doctorales. Especializado en lenguajes formales y en lenguaje de la fe, en filosofía de la ciencia, filosofía del lenguaje y filosofía social. En su tesis doctoral sobre el teorema de Gödel212 demostró que ningún lenguaje o sistema puede justificarse por sus propios medios y que, para hacerlo, necesita recurrir a un lenguaje de otro nivel. Es decir, reflexionó sobre los límites de la racionalidad ${ }^{213}$, con la inquietud, entonces difusa, por la confrontación entre la razón y la fe, que siempre constituyó el eje de su existencia. En una entrevista con motivo de $80^{\circ}$ aniversario hacía el siguiente ejercicio de 'hermenéutica vital' sobre la existencia en general y sobre su propia trayectoria: "Lo que está en juego no es una simple confrontación, es una relación justificable, a la vez reflejada y vivida, entre fe y razón. Es la perspectiva de esta relación lo que está, creo, subyacente en la gran mayoría de los textos que escribí, mientras que los otros son solamente intervenciones de circunstancia" 214 . Nos preguntábamos sus alumnos si siempre habría sido el profesor J. Ladrière así y la picaresca estudiantil hacía comentarios que iban de lo melodramático hasta lo sentimental y lo gracioso 215 .

El centro de gravedad de su vivir y de su pensar según sus propias palabras: "ce n'est pas une simple confrontation, c'est un rapport justifiable, à la fois réfléchi et vécu, entre foi et raison" 216 . En virtud de esta exigencia de justificación se impuso el ingente trabajo de minuciosos análi-

Renta Básica (BIEN), hoy Red Global de Renta Básica, cuyo comité internacional preside, coordinador del Foro Ético de la Fundación Universitaria.

212 LADRIÈRE, J., Les limitations internes des formalismes. Étude sur la signification du théorème de Gödel et des théorèmes apparentés dans la théorie des fondements des mathématiques, 1957.

213 LADRIÈRE, J., El reto de la racionalidad. La ciencia y la tecnología frente a las culturas, Sígueme-Unesco, Salamanca 1978.

${ }^{214}$ En una entrevista concedida a la revista de Lovaina con motivo de su $80^{\circ}$ aniversario.

215 Se decía, por ejemplo, que al comienzo de su carrera universitaria había sido un profe muy exigente, tanto que un alumno se le suicidó y que desde entonces había dado un giro copernicano a su vida; otros lo achacaban a un desengaño sentimental (y ahí entraba la picaresca estudiantil atribuyéndole novietas de toda la escala social y académica: una fornida moza flamenca (en contraste claro con el exiguo porte de Ladrière), dos profesoras de filosofía de entonces: madame Mansion (sobrina del especialista en Aristóteles), madame Florival, algo regularcillas, la verdad. Y claro, frente a ellas, alguien tan íntegro como el casto José-Ladrière, se comentaba con sorna y risas garantizadas. Nunca se pudo averiguar, si fue cierto. Corramos un tupido velo - ¡Misterio!- y vayamos a lo serio.

216 "No es una simple confrontación, es una relación justificable, al mismo tiempo reflexionada y vivida, entre fe y razón". 
sis $^{217}$, amplia documentación, honesta confrontación con otros colegas -muchas veces ateos o descreídos- y con sus mismos estudiantes. En la semblanza que hizo Van Parijs con ocasión de su muerte dice de él: "Católico comprometido, Jean Ladrière no era de los que consideraban deber imponer su fe a los otros o despreciar a los que no la compartían con él. Ofrecen testimonio de ello los fuertes lazos de amistad y de estima que ha mantenido, por ejemplo, con Chaim Perelman y Leo Apostel, con Jean Van Lierde y Jules Gérard-Libois", mas bien ajenos a la fe, cuando no militantemente contrarios a ella. En una entrevista, haciendo balance de su vida, afirma con gran cordura y serenidad: "Veo sobre todo el carácter muy inadecuado, demasiado parcial y demasiado tímido de lo que pude expresar. (...) En cualquier caso, que haga lo que haga o que no lo haga, sé que no podrá haber adecuación entre lo que habré podido eventualmente hacer y lo que habría debido hacer. Esta es la razón por la que, desde ahora, confío enteramente en la misericordia de Dios”. ¡Sabia distinción y perspicaz matización entre saber, querer, poder y hacer! ¡Sabio ejercicio hermenéutico sobre Quién evalúa definitivamente lo que hacemos siendo! Lúcida coherencia.

J. Ladrière ha prestado especial atención a lo que él ha llamado 'el lenguaje de la fe"218. Lo describe en estos términos: "La foi est sans doute un mouvement de l'esprit, mais elle doit se dire (...) la foi met en oeuvre un langage"219. "Mais, si elle se dit dans une parole, elle se vit dans des gestes, dans un comportement, qui sont comme l'echo de cette parole et qui sont eux-mêmes signes" 220 . La palabra de la fe tiene una envergadura escatológica.

Las muchas variaciones sobre el tema del lenguaje las ha ido interpretando $221 \mathrm{~J}$. Ladrière a lo largo de su vida con la destreza, con que un hábil organista ejecuta diferentes series de arpegios, para hacer sonar los más variados armónicos de una partitura bachiana: junto al lenguaje lógi-

217 Veo cierta similitud entre M. Blondel y J. Ladrière en este proceso. También en otros rasgos característicos de sus respectivas personalidades, aunque vividas en circunstancias históricas y eclesiales tan diferentes.

218 LAdrière, J., "Le langage de la foi", en Foi, Enciclopaedia Universalis, Paris 1980, 7, 75-78; MALHERBE, J.-F., Le langage théologique à l'âge de la science. Lecture de Jean Ladrière, Cerf, Paris 1985.

219 "La fe es sin duda un movimiento del espíritu pero debe decirse ...la fe pone en marcha un lenguaje" (LADRIÈRE, J., "Le langage de la foi", 76).

220 "Pero si se dice en una palabra, se vive en gestos, en un comportamiento, que son como el eco de esta palabra y que ellos mismo son signos" (ibid., 78).

221 En francés 'jouer', en alemán 'spielen', un instrumento una pieza teatral traduce nuestro tocar, 'interpretar', que mantiene a su vez el aire de familia del juego y de las artes escénicas, en el interior del vasto ámbito de la hermenéutica. 
co, el litúrgico 222 , teológico 223 , bíblico ${ }^{224}$, místico ${ }^{225}$. Para decir algo de lo que mucho que dijo digamos 226 : En el lenguaje de la fe, dice él, bajo la apariencia de expresiones constatativas hay una performatividad 227 estructural, que remite a la realización de un plan de salvación, en que están implicados Dios y el ser humano; al proferir sus expresiones y por el hecho de hacerlo, y al hacerlo con determinadas condiciones -toma cuerpo un compromiso en el locutor y en el interlocutor, entre ambos, porque se produce una como implicación biunívoca, un compromiso que es correlativo con la salvación. Otra característica de este tipo de lenguaje es que opera una cierta 'transgresión' del lenguaje, al utilizar términos que le son propios y dotar a otros de significados, que no son los de su uso ordinario. Una de las consecuencias inmediatas de esa praxis es que moldea y configura la realidad, también la personal, conforme a modelos de su lógica peculiar. Es un tipo de discurso muy diferente del especulativo en cuanto que es, al mismo tiempo, un lenguaje de verdad y de compromiso. "El lenguaje de la fe hace aparecer la realidad que evoca sólo mediante el compromiso que expresa"228. Lo propio de él no es tanto formular proposiciones -aunque en él haya profesiones de fe- hacer declaraciones, manifestar adhesiones a fórmulas especulativas, cuanto expresar 'vinculaciones existenciales' y 'compromisos de vida'. Es, por tanto, un dominio privilegiado para llevar a cabo lo que vengo llamando 'herme-

${ }^{222}$ LADRIÈRE, J., "La performatividad del lenguaje litúrgico", en La articulación del sentido, Sígueme, Salamanca 2001,311-321.

223 "El lenguaje teológico y su verdad", ibid., 395-410.

224 "La performatividad del relato evangélico", ibid., 279-296.

225 "El lenguaje de los espirituales", ibid., 323-340.

226 Pronto aparecerá un trabajo mío sobre el tratamiento del lenguaje, que ha hecho J. Ladrière.

${ }^{227}$ Este lenguaje se inspira en las teorías de L. Wittgenstein, J.L. Austin, J.R. Searle; BRIGGS, R., "The Use of Speech Acts Theory in Biblical Interpretation", en Current Research in Biblical Studies 9 (2001) 229-276; "Getting Involved: Speech Acts and Biblical Interpretation", en Anvil 20 (2003) 25-34; Words in Action: Speech Acts Theory and Biblical Interpretation: Towards a Hermeneutic of Self-Involvement, T\&T Clark, Edinburgh 2001; BothA, E., Jesus and the Samaritan Woman: A Speech Act Reading of John 4,1-42, E.J. Brill, Leiden 1991; Downing, F.G., Doing Things with Words in the First Christian Century, Sheffield Academic Press, Sheffield 2000; Neufeld, D., Reconceiving Texts as Speech Acts: An Analysis of 1 John, E.J. Brill, Leiden 1994; RHOADs, D., Performance Criticism: An Emerging Methodology in Biblical Studies, Lutheran School of Theology at Chicago, s.d; HART, T.A - GuTHRIE, S.R. (ed.), Faitful Performances: The Enactment of Christian Identity in Theology and the Arts, Ashgate 2005; RHOADs, D., "Performing the Gospel of Mark", en Body and Bible: Interpreting and Experiencing Biblical Narratives, Trinity International Press, Philadelphia 1992, 102-119; PERSON, R.F., "The Ancient Israelite Scribe as Performer", en Journal of Biblical Literature 117 (1998) 601-609.

228 Ibid., 255. 
néutica vital'. Por eso, pronunciar 'yo creo en...', 'yo creo a...' queriendo hacerlo y asumiendo el significado de esas expresiones y las consecuencias que se derivan de ellas, equivale a adherirse realmente a personas y a contenidos $^{229}$.

\title{
6. Adolphe Gesché: la honradez elegante de un teólogo cabal
}

\author{
"C'était au temps où Bruxelles bruxellait"230 \\ "Corremos un gran riesgo de instrumentalizar a Dios"231
}

Por lo que concierne al recuerdo sobre mi maestro el profesor Adolphe Gesché (1928-2003) ${ }^{232}$, diré que enseñó durante muchos años en el Seminario Mayor de Malinas (Bélgica) y luego, como catedrático de teología dogmática, en la Facultad de Teología de la Universidad Católica de Lovaina. Seguí sus lecciones como alumno ordinario durante dos cursos académicos, para licenciarme en teología, e hice además con él los cursos para el doctorado. Con A. Gesché tardabas en entrar, era discreto y medía las distancias, sin ser ni elitista ni evasivo, simplemente respetaba el espacio de cada cual y el rol que desempeñaba en él, era pulcro y afable, tímido hasta un rubor adolescente pero con una elegancia intelectual, que trasparentaba en todas sus intervenciones, gestos y actitudes; vocación tardía al sacerdocio -entró en el Seminario de Malinas con ventitrés años-, después de licenciarse en filosofía y tras un serio discernimiento; desempeñó tareas pastorales de capellán y de coadjutor; celebraba la misa con gran devoción -nos hospedábamos en el mismo colegio y participé en ellas muchos días-; metódico, ritual, respetuoso, casi nunca tuteaba a sus alumnos; jamás lo vi crispado, ni hacer ostentación de sus muchos y pluridisciplinares conocimientos; con muy buena preparación en filología, estética, patrología, cultura clásica presentó, en 1958 en Lovaina, su tesis doctoral en teología titulada: "Le 'Commentaire sur les

229 'La fe es un acto humano', en CEC 154; El lenguaje de la Fe', ibid., 170-171.

230 J.Brel, Bruxelles. Tanto A. Geshé como J. Brel son de Bruselas. Comparten señorío y casta. ¡Pero tan distintos! Provocador, desenvuelto, divertido Jacky; matizado, tímido, ponderado Adolphe. Ambos locuaces y de cálido hablar, comprometidos también.

231 Gesché, A., El sentido, Sígueme, Salamanca 2004, 19: "Afirmar sin más que Dios es el sentido del sentido implica despreciar la consistencia del sentido"; "el sentido no sustituye a Dios y Dios tampoco sustituye al sentido".

232 Haquin, A., "Décès du professeur Adolphe Gesché", en Revue Theologique de Louvain 35 (2004) 151; "In memoriam Adolphe Gesché", en Ephemerides Theologicae Lovanienses 80 (2004) 153-154. 
Psaumes découvert à Toura'. Étude documentaire et littéraire”. En 1962 obtuvo la maestría para enseñar teología con el trabajo: "La christologie $d u$ 'Commentaire sur les Psaumes découvert à Toura”233. En 1987 organizó en la UCL los 'Coloquios Gesché'. A lo largo de los años fue constituyendo un fichero muy variado con material interdisciplinar, donde volcaba citas y comentarios de sus lecturas interesadas por tantos temas, que luego le servirían para confeccionar su magna obra, publicada en torno al tema general Dios para pensar, de la que han aparecido siete volúmenes también en español234. Entre los reconocimientos recibidos sobresalen el 'Premio de los Escritores Cristianos' en 1998 y, el mismo año, el Premio de Filosofía de la Academia Francesa. En los últimos días de su vida dijo a su familia: "Mi pasión fue Dios. Yo no tengo otra palabra para decirlo"235. De su obra se dice que fue solicitada, situada y diversa. Se dice que es una 'obra solicitada' desde el exterior por las demandas que se le hacían e interior por el propio dinamismo de los problemas examinados. Pero también 'situada' porque responde a circunstancias concretas de tiempo y de lugar. Finalmente es también una obra 'diversa' como lo son los destinatarios y los problemas abordados. En su haber cuenta con la dirección de un gran número de tesinas y de tesis doctorales. Entre ellas, cuyos títulos figuran en la Bibliografía Completa publicada por la UCL, las hay tanto sobre teología de la liberación como sobre trasfondo filosófico. Buena muestra de ello son las que dirigió a dos compañeros míos, la de Clodovis Boff, hermano de Leonardo Boff, que trabajó sobre epistemología de la teología, y la del jesuita de origen cubano Emilio Brito, que lo hizo sobre la cristología de Hegel, o los trabajos de la primera fase de la mía sobre Maurice Blondel, en colaboración con el historiador de la Iglesia R. Aubert y el con C. Troisfontaines, director de los archivos M. Blondel en el Institut Supérieur de Philosophie de la UCL.

A la hora de sistematizar su pensamiento teológico A. Gesché no duda en recurrir a las ciencias humanas, muy especialmente la antropolo-

233 B. Bourgine, P. Rodrigues, P. Scolas (éd.), La margelle du puits. Adolphe Gesché, une introduction, Paris, Cerf, 2013; P. Rodrigues, Pensar al hombre. Antropología teológica de Adolphe Gesché (Bibliotheca Salmanticensis. Estudios, 333), Salamanca, Publicaciones Universidad Pontificia, 2012; S. García Mourelo, La Fe como patria del Logos. La tarea y el método en la teología de Adolphe Gesché, Madrid, Comillas, 2009, tesina.

234 A.Gesché, Dios para pensar: I. El Mal; II. El Hombre; III. Dios; IV. El Cosmos; V. El Destino; VI. Jesucristo; VII. El Sentido. Todos ellos en Salamanca, Sígueme, entre 1995 y 2004.

235 En la introducción a su Bibliografía Completa, realizada por la UCL, se dice que esa frase la pronunció con ocasión de su $75^{\circ}$ aniversario y que es la mejor clave "para entrar en una obra muy particular". 
gía ${ }^{236}$, la hermenéutica y las ciencias del lenguaje. No es un ingenuo, ni un advenedizo, en el campo de la teología -aunque sus publicaciones hayan tardado mucho en llegar- como lo muestra en reflexiones sutiles como ésta:

La teología no puede acabar en antropología 237 (....) No se trata, pues, en absoluto, de que la teología, avergonzada de sí misma, abdique de sus responsabilidades de hablar sobre Dios (...) no deja de ser verdad que ella es también un discurso sobre el hombre (...) ¿de qué hombre habla la teología? (...) ¿cómo habla de él la teología? (...) hablar de él al hablar de Dios (...) un Dios que tiene algo que decir al hombre (...) Sin duda se podrá convenir en que la teología es discurso sobre el hombre-que-habla-de-Dios (...) La teología hablará del hombre con el lenguaje que le viene del Incondicionado, del que saca su justificación ${ }^{238}$.

Habiendo argumentado a favor de la plausibilidad de una reflexión 'teológica' sobre el hombre desde Dios, termina con una pregunta: “¿Está prohibido leer al hombre in excelsis?”239. Claro que no, me apresuro a responder, puesto que Dios lo ha prohijado con su bendición eligiéndolo, en la persona de Cristo, antes de crear el mundo, para que fuese santo e irreprochable, ante Él, en el amor ${ }^{240}$ y luego ha emprendido el camino-descendit de coelo- para devenir precisamente hombre.

Cuando A. Gesché plantea el problema de Dios, no lo hace del modo al uso. Parte de una perspectiva que bien podríamos llamar 'lingüística'. Sus primeras palabras en lo que podríamos llamar un tratado sobre Dios son éstas:

La palabra Dios existe. Esta es, sin duda, la única certeza unánime, Luego uno se las ve y se las desea para saber si esta palabra tiene o no contenido. Pero la palabra existe, como una vieja medalla, con su relieve hoy casi borrado, casi ilegible, y de la que uno sabe, como de

236 GESCHÉ, A., 'La teología como discurso sobre el hombre', en Dios para pensar I. El mal - el hombre, Sígueme, Salamanca 1995, 210-232; “¿Cómo hablar de Dios? La cuestión del quomodo", en Dios para pensar, II Dios - El cosmos, Sígueme, Salamanca 1997, 30-35; “CCómo habla del hombre la teología?”, en Dios para pensar, I, 216-232.

237 Como pensaba L. Feuerbach en La esencia del Cristianismo (1841).

238 Gesché, "La teología como discurso sobre el hombre", en Dios para pensar I, 209 ss.

239 Ibid., 232.

240 Ef 1,4 . 
toda inscripción, que una vez, al menos -y más de una vez- fue estrenada y pronunciada como una palabra llena de sentido. Y uno llega a adivinar o presentir que esa palabra, como una efigie grabada con una inscripción indeleble, permite al hombre expresar lo más precioso y misterioso $^{241}$.

Este modo de cuestionar también asume el planteamiento de aquellos para quienes Dios es únicamente un nombre. En realidad, en todo el proyecto teológico de A. Gesché, es el punto focal desde el que lo desarrolla. Recurriendo también a la narratividad ${ }^{242}$ como instrumento expresivo y materia de reflexión.

Teólogo de raza sale al encuentro de los cuestionamientos negativistas con el ánimo de buscar puntos de anclaje donde engarzar su reflexión. Ello le lleva a preguntarse: “¿Dónde estaría, pues, el lugar natal243 de Dios? ¿Dónde se le encontraría, de alguna manera, en sí mismo?”244. Esto implica una opción epistemológica de gran alcance:

"Hablar de una búsqueda de Dios en su lugar natal significa que uno propone como camino el de la hermenéutica de una religión concreta. La fenomenología nos proporciona una de las conquistas más fecundas de la nueva racionalidad: búsqueda de la inteligibilidad de la 'cosa' en el lugar mismo en el que ella se da (wo und wie sie sich gibt). Aquí: búsqueda de Dios allí donde se habla de él y, a partir de ahí, poner al día aquello de que se trata"245.

Emprende la convicción expresada con palabras de Montaigne: "La palabra es mitad del que habla, mitad del que escucha". Muy en la línea de P. Ricoeur quien, al apostar por la autonomía del texto, atribuye una gran importancia al 'lector' en el proceso de comprensión. En este caso, al comenzar preguntando 'cómo' (quomodo) hablar de Dios, responde Gesché que se condiciona el contenido de la respuesta, porque en ese

241 Gesché, A., Dios para pensar II: Dios - Cosmos, Salamanca, Sígueme, 1997, 11; CASTElli, E., L'Analyse du langage théologique.

242 Gesché, A., "'La 'sorpresa' de Dios. Perspectivas de teología narrativa”, en Dios para pensar I: El mal - el hombre, Sígueme, Salamanca 1995, 51-66. Ricoeur, P., 'Los 'mitos' del principio y del fin', en Finitud y culpabilidad, 447-698.

243 Ante los malentendidos que arrastra el término 'revelación', propone dejarlo por el momento: "me gustaría introducir aquí el concepto de lugar natal. Lugar natal de Dios: el lugar o un lugar donde él va como a nacer entre nosotros" (1.c., 13). Y lo hará gracias al lenguaje.

244 GESCHÉ, Dios para pensar II, 14.

245 Ibid., 15. 
caso lo prioritario no es definir a Dios en sí y por sí o determinar los atributos, que componen su identidad, su esencia, sino si es alguien para el hombre; dónde hallarlo y, si se le halla, cuáles son los términos más adecuados para describir la experiencia del encuentro. De las tres preguntas sobre Dios -an sit, quid sit, quomodo sit- elige la tercera como la más pertinente para nuestro tiempo. Al concretarla en ¿cómo (se) habla de Dios hoy? lleva a cabo lo que se podría llamar un 'giro lingüístico' de la Teología. De todo ello se deduce que, si la realidad de Dios se ha dado en el lenguaje, habrá que averiguar, en ese 'topos' que es el lenguaje, lo que ella sea, convirtiéndose así, por esta razón, en la 'questio princeps' 246 para la teología: “¿qué nos ofrece esa experiencia lingüística. El lenguaje da a luz"247. Es un hecho irrefutable, argumenta Gesché, que un día, unos hombres, inventaron la palabra 'Dios' y que, al menos desde entonces, también ha habido y hay hombres que han creído y creen en el contenido del que es portadora; y que nada de lo que alguna vez tuvo sentido para el hombre se puede dar por inexistente o por perdido 248 .

No se trata de un cambio menor sino de un verdadero vuelco: plantear la cuestión del ser a partir del lenguaje, averiguar la realidad a partir de la manera (modus quo), "a partir del 'quomodo' lingüístico". En proximidad, por cierto, con M. Heidegger. Por esta razón afirma A. Gesché que a ese proyecto de ontología del lenguaje, puesto que se refiere a Dios, "podríamos denominarlo 'teología' del lenguaje"249. Piensa que ese es un buen filón para seguir pensando-Dios para pensar-sobre todo si se tiene en cuenta que enlaza con la tradición bíblica, que da tanta importancia a la relación Dios y Palabra ${ }^{250}$. No es de extrañar, piensa, que la nueva pregunta -o la reformulación de la pregunta tradicionalhaya saltado al primer plano de la reflexión. La cuestión permanece abierta y él la formula en estos términos: “¿qué nos enseña y revela esa palabra 'Dios' con la que el hombre (quo-modo) enuncia y encierra una experiencia hasta tal punto fundadora y fundamental, que esta palabra resulta a la vez el término más usado y el más cargado?"251.

246 Erróneamente se dice 'questio' en lugar de 'quaestio' 34. También en otros lugares.

247 GESCHÉ, Dios para pensar II, 34.

248 Buber, M., Eclipse de Dios, Sígueme, Salamanca 2003, 37ss.

249 Ibid. El propio P. Ricoeur ha reflexionado sobre el tema: "Reflexión sobre el lenguaje. Hacia una teología de la palabra”, en Exégesis y Teología, 237-253.

250 SCHILlEBEECKX, E., "Revelación-suceso y Revelación-Palabra", en Revelación y Teología, 41-62.

251 GESCHÉ, Dios para pensar II, 35. 
La reflexión teológica de A. Gesché se abre paso también por los dominios de la 'narratividad', corriente que ha suscitado muchas expectativas en teología 252 . Al buscar los fundamentos doctrinales a partir de los cuales se ha tratado el problema del mal, dice que se deben tener en cuenta los términos en los que la propia Biblia lo ha tratado, como el referente obligado. Ella lo ha hecho en términos narrativos que por sí mismos ya contienen un mensaje. No es indiferente, como ha señalado $P$. Ricoeur al hablar de hermenéutica bíblica, el género en que se expresa la Revelación. Son mucho más que meras figuras de estilo ${ }^{253}$, porque también contienen mensaje dentro de su propia singularidad significante. Así, por ejemplo, no es lo mismo que algo sea dicho en un himno que en un relato; en una parábola, o en un discurso didáctico; en un canto de alabanza o en un discurso parenético. No es lo mismo 'cantar' que 'contar'. $\mathrm{Su}$ diferente fuerza ilocucionaria implica de modo diferente e induce a comportamientos distintos con grados de obligatoriedad propios. De ahí que, si la Biblia elige un determinado género para decir algo, se tenga en cuenta y se saquen conclusiones. Argumenta A. Gesché:

Para el Génesis, si nos atenemos a una lectura hermenéutica del texto, 'el mal es lo que estaba previsto'. En el relato de la creación no sólo no se crea el mal, sino que ni siquiera se le menciona: no pertenece al plan, a la idea de la creación. Esto significa que el mal está desprovisto de sentido (...) Pero el mal existe. Después de la creación -y es el segundo gesto teológico-, el relato bíblico constata la aparición y el hecho del mal254.

En los relatos, en éste, lo mismo que en el del diluvio, el de Sodoma y Gomorra, en los otros, siempre hay algo así como una 'teología diluida' -diría yo-, un modo de presentar la trama de la historia de la salvación, las reacciones y pensamientos de Dios y de los demás agentes, que obran en las 'historias narradas'. La teología sistemática, al leer esos relatos, también puede tomar una forma narrativa. En el caso concreto de la reflexión sobre el mal puede adop-

252 FreI, H.W., Theology and Narrative, Selected Essay, Oxford University Press, New York-Oxford 1993; GoldBerG, M., Theology and Narrative, A critical Introduction, Trinity press International, Philadelphia 1991.

${ }^{253}$ El lenguaje común lo recoge en expresiones como 'lo dijo en un tono que', 'lo dijo con un tono...', 'lo dijo con retintín', 'no me hables en ese tono', ‘¿crees que esas son formas de hablar?', 'me dijo... como queriendo decir', etc.

254 GESCHÉ, Dios para pensar II, 51. Narratividad que también practicó E. Schillebeeckx en su Cristología; EsPEJA PARDO, J., "Cristología narrativa de E.Schillebeeckx", en Ciencia Tomista 109 (1982) 139-173. 
tar, y de hecho adopta en A. Gesché, un modo de presentación descriptivo, narrativo, acorde con la estrategia narrativa del material sobre el que reflexiona. En los relatos hay, como dice P. Ricoeur, 'una estrategia narrativa' que debe ser tenida en cuenta por la teología ${ }^{255}$, porque es en ella donde radica el sentido del mensaje. Así, el relato de la caída no atribuye una culpabilidad inmediata ni a Dios ni al ser humano. Lo cual tiene consecuencias muy importantes para el futuro desarrollo de sus relaciones y de la responsabilidad: "Si Dios y el hombre son inocentes en el relato bíblico del Génesis, el primer problema verdadero de la responsabilidad puede plantearse de otro modo: ¿cómo obrar ante el mal? ¿qué hay que hacer? ¿cómo salir de él?”’256. Como consecuencia de asumir con mayor rigor el relato, se amplían las perspectivas de la comprensión. El resultado de tomar así las cosas es sorprendente porque, en lugar de abocar a una 'responsabilidad de perdición', apunta a una 'responsabilidad de salvación'.

Mirada desde la perspectiva de los planteamientos teológicos tradicionales, puede afirmarse que se trata de que "esta inversión resulta paradójica" y proporciona, además, una segunda lección: la del tema del mal como sorpresa: "La de llamar al mal por su verdadero nombre, a saber, irracional, puesto que el primer gesto consiste, aquí, en verse sorprendido. No es éste, desde luego, el reflejo clásico de la teología" ${ }^{257}$. No le duelen prendas a $\mathrm{A}$. Gesché en reconocer que hay mucho que ganar y poco que perder, cuando se recurre, como aquí, a la narratividad. Dando pruebas de honestidad intelectual muestra uno de los flancos vulnerables de la teología tradicional, a la que ha guardado una fidelidad tan exquisita: "La teología tiene la costumbre de comprender y explicar las cosas: por ejemplo, en este caso, apelando inmediatamente a la noción de culpabilidad. Pero comprender y explicar es muchas veces rechazar la prueba de la sorpresa" 258 . Aquí, entre líneas, remite A. Gesché al ámbito de la hermenéutica para escrutar el alcance de lo que supone comprender y explicar ${ }^{259}$ un texto, para

255 Ricoeur, P., "Toward a Narrative Theology: Its Necessity. Its Resources, Its Difficulties", en Wallace, M.I. (ed.), Figuring the Sacred, Minneapolis 1995, 236-248.

256 GESCHÉ, Dios para pensar II, 54.

257 Ibid., 55.

258 Ibid., 55. A. Gesché, desmarcándose de cierta tradición teológica integrista en la comprensión mal dice: "Prefiero una vez más a San Francisco de Sales (Tratado del amor de Dios II, 11, 99) cuando afirma:'No es necesario pensar que se puede dar razón de la falta que se comete pecando, pues la falta no sería pecado si no se cometiese sin razón” (ibid., 56).

259 "En el fondo, la correlación entre explicación y comprensión, entre comprensión y explicación, es el círculo hermenéutico" (RICOEUR, P., "La acción considerada como un texto", en Hermenéutica y acción, Editorial Docencia, Buenos Aires 1985, 73); RIcoeur, 
que la propia teología ajuste la práctica de su comprensión. Igualmente el relato aporta nuevas perspectivas sobre la 'prioridad de la víctima', la 'fragilidad del hombre': tentado, frágil, liberado, víctima, desviado. La ganancia de semejante proceder -reflexionar a pie de relato- es grande para la teología y para la vida cristiana en general: "Al mostrar que el mal sobreviene por sorpresa y al señalar de dónde viene, la teología desenmascara toda su malicia" 260 y permite organizar una estrategia liberadora muy alejada de aquella, que sumía al ser humano bajo el peso de la culpa y hacía poco menos que imposible su rehabilitación, con el consiguiente menoscabo de la eficacia de la gracia. A.Gesché se refiere a ello llamándolo 'moralismo de culpabilidad', 'moralismo de culpabilización', 'moralismo de justificación' sutil e inconsciente del mal ${ }^{261}$. Consecuente con esta modificación de actitud no se limita a proponer simples cambios de modalidad, a la hora de abordar estos problemas donde hay tanto en juego. Se atreve a realizar, con todas las consecuencias, una "re-dogmatización del misterio del mal" 262 , una re-ordenación de su topografía 263 y un nuevo planteamiento de "teología salvífica"264. Aunque imprescindible, no se le antoja fácil la tarea, de ahí que se manifieste en estos términos: "La cordura de los conceptos y de la moral ¿está a la altura -y a la desmesura- de esa enormidad que es el mal?" 265. Es tan grande el beneficio a obtener, que bien vale la pena reformularlos en propuestas audaces de liberación.

Un cambio de actitud, como éste de A. Gesché, en el quehacer teológico no es fácil. Sobre todo cuando pesa sobre las espaldas una historia tan larga de haberlo hecho de otro modo, estar en semejante punto de mira como la UCL, ser un terreno tan resbaladizo y tan sometido a supervisión canónica. Son muchos los teólogos que se han quemado en el intento, han sido objeto de una purga severa, o se han visto relegados al ostracismo, por practicar una reflexión fronteriza y compasiva. La estrategia de la teología ha sido frecuentemente dar mucha importancia al principio de autoridad cerrándose a métodos novedosos. Cuando les ha

P., "Expliquer et comprendre", conferencia de P.Ricoeur en Louvain-la-Neuve, 24.9.1976; Id., "Expliquer et comprendre, homenjae a H.G.Gadamer", en Du texte à l'action. Essais d’herméneutique II, Seuil, Paris 1986; Pérez Chico, D. - Rodríguez SuÁrez, Ma Luisa Paz (ed.), Explicar y comprender, Plaza y Valdés, Madrid 2011; Cubides C., H.J., "La dialéctica comprender/explicar: Una reflexión filosófica desde la hermenéutica", en Nómadas 11 (1999) 267-273.

260 GESCHÉ, Dios para pensar II, 66.

261 Ibid., 68-73.

262 Ibid., 73-80.

263 Ibid., 80-85.

264 Ibid., 85-102.

265 Ibid., 86. 
prestado atención, ha visto cómo era descalificada como 'nueva teología' y puesta en entredicho, denostada, ridiculizada, proscrita, pero justamente rehabilitada en el Concilio Vaticano II, del que únicamente se ha realizado la recepción y promovido lo que ha interesado a determinadas sensibilidades. Hay quien piensa que, de un tiempo a esta parte, hay corrientes involutivas muy fuertes en el seno de la Iglesia, que afectan a nombramientos episcopales y otras responsabilidades en Dicasterios, Nunciaturas, Seminarios, Curias, Delegaciones, Vicarías, Facultades, Medios de Comunicación, nombramientos de obispos, pastoral vocacional, incluso en responsabilidades de la pastoral de a pie ${ }^{266}$. Por un lado se pide la descentralización y por otra se apuntalan estructuras intermedias conservadoras, se laminan los disensos y se condena al ostracismo a los críticos. A. Gesché ha sido prudente, discreto, elegante en sus planteamientos teológicos, pero astuto y valiente. No buscó la confrontación pero tampoco rehuyó la denuncia. Por eso buscaban sus enseñanzas personas de muy diferentes sensibilidades, de la liberación como Clodovis Boff, hermano de Leonardo, teólogos sistemáticos y conservadores como el jesuita de origen cubano Emilio Brito, monjes de Orval y de Chimais, sacerdotes en formación permanente, capellanes de emigrantes, obispos, candidatos al sacerdocio europeos, latino americanos, africanos, novicias, misioneros, asociaciones de piedad o militantes cristianos.

A. Geshé ha transitado por la teología con lucidez, respeto, mesura, decisión, parsimonia, disciplina, espíritu de diálogo intercultural e interconfesional y un muy acentuado sentido de Iglesia. Jamás lo vi queriendo aparecer como el primero en algo. Siempre 'sentado al fondo de la sala del banquete', como un discípulo menor, que gusta de estar en la sombra pero no a la sombra de, hasta que quien preside la mesa quiera decirle: 'ven a ocupar este puesto junto a mí'. No fue, desde luego, un teólogo de la talla de sus colegas belgas, Schillebeeckx, Philips, Dondeyne, Delhaye, Thils, Descamps, Dupont... ni tomó parte en la primera fila de los que prepararon el Vaticano II o asesoraron en él, aunque frecuentó muy de cerca a uno de sus principales artífices, al imponente -iporque verdaderamente imponía!- cardenal L.J. Suenens. Tuvo, sin embargo, la responsabilidad de hacer su recepción y divulgarlo, mientras era profesor de teología en el Seminario Mayor de Malinas y como profesor en la UCL,

266 Tamayo, J.J., Juan Pablo II y Benedicto XVI. Del neoconservadurismo al integrismo, RBA, Madrid, 2011. Sin llegar a estos extremos, auto-interpretados como 'progresistas', hay quienes piensan, con matices, que la Iglesia va hoy sin rumbo, dando palos de ciego, más preocupada por la apariencia, la beneficencia y la maledicencia, que por ser, y por estar en la pomada complicándose. 
extraordinario durante media docena de años y luego ordinario hasta su jubilación. Sus principales escritos -completados por centenares de artículos, exposiciones, ensayos- han sido publicados bajo el título general de 'Dios para pensar'. Han aparecido siete volúmenes, que recorren a grandes rasgos todo el espectro de la teología. En el último de ellos ${ }^{267}$, Dios para pensar VII: El sentido, dice algo específico, que vale para el tema que desarrolla en este volumen, pero pienso, conociéndolo, que se puede aplicar como síntesis a todo su talante de teólogo y me vale como cierre: "Hablar de Dios, de la caridad, de la fe, es actuar de manera que cada cosa pueda comprenderse, aunque sólo sea por un instante, desde la perspectiva del exceso, de la inversión del orden de las cosas, de la conversión de las miradas, de la transgresión de la regla de lo simplemente debido"268. Así pretendió ser y fue su propia teología, en la que habla frecuentemente de que, para comprender a Dios, siempre de modo asintótico, hay que tener en cuenta lo que él llama 'el principio del exceso', que se refiere a que Dios sorprende siempre superándose omnipotentemente en generosidad, misericordia, benevolencia, humildad... simplemente porque es Amor.

$\mathrm{Al}$ mismo tiempo que la docencia de teología sistemática y la preparación de sus publicaciones, organizó una serie de encuentros sobre el diálogo fe y razón, los 'Coloquios Gesché'269, a los que invitaba a personalidades de primer orden del campo del pensamiento y de las artes. Olegario González, prologando la edición en castellano del volumen VII de 'Dios para pensar', comenta que A.Gesché, al tratar del 'sentido', “ofrece una respuesta hermenéutica, con Husserl, Levinas y Ricoeur en el fondo, describiendo los lugares donde el sentido es vivido, porque previamente

267 Además de Dios para pensar, ha escrito otras obras, cuyos testimonian su amplitud de miras y su vasta cultura: Pensées pour penser. Vol I: Le mal et la lumière, Cerf, Paris 2003; Pensées pour penser. Vol. II: Les mots et les livres, Cerf, Paris, 2004; La paradoja del cristianismo. Dios entre paréntesis, Sígueme, Salamanca 2011 que reúne tres artículos suyos; La paradoja de la fe Salamanca, Sígueme, Salamanca 2013, que reúne cuatro artículos suyos.

268 Gesché, A., Dios para pensar VII: El sentido, Sígueme, Salamanca 2004, 23.

269 Coloquios Gesché en la UCL; Destin, prédestination, destinée, Cerf, Paris 1995; La foi dans le temps du risque, Cerf, Paris 1997; La Sagesse, une chance pour l'espérance?, Cerf, Paris 1998; Dieu à l'épreuve de notre cri, Cerf, Paris 1999; Et si Dieu n'existait pas?, Cerf, Paris 2001; Sauver le bonheur, Cerf, Paris 2003; Le corps chemin de Dieu, Cerf, Paris 2005; L'invention chrétienne du péché, Cerf, Paris 2007; Qu'est-ce que la vérité?, Cerf, Paris 2009; La transgression chrétienne des identités, Cerf, Paris 2012; Dieu au risque des religions, Cerf, Paris 2013; Intempestive éternité, Cerf, Paris (publicación prevista para 2015). Maldame, J.-M., "L'anthropologie Théologique de A. Gesché. De l'excès au mystère par le chemin de l'énigm", en Revue d'éthique et de Théologie Morale, 232 (2004) 77-93. 
aparece como revelación y reto, don y pregunta" 270 . Al mismo tiempo comenta el que A.Geshé llama 'principio del exceso', principio que en los tiempos presentes tiene un alcance diferente al que tuvo en el medievo: Dios es visto como excesivo no en razón de su omnipotencia, que no se cuestiona $^{271}$, sino de su infinita misericordia y gratuidad, que se empeña absolutamente por la salvación del ser humano. Y es ahí donde aparece también lo novedoso del punto de vista adoptado por A. Geshé. En definitiva, sólo desde una perspectiva como ésta, de la existencia como don y empeño, se recupera el sentido y es de esperar que la teología, en proximidad y solidaria, esté allí para contarlo 272 . Buscar el nombre para nombrar al Innombrable, que da el ser y reparte la tarea, referirse a Él como mejor convenga - ¿cuál es su nombre?”273_ acudiendo cuando invita (fascinans), no huyendo cuando impone (tremendum), es la actitud que cabe esperar del creyente responsable y maduro. Articular los diferentes modos de nombrar a Dios mediante los instrumentos, que proporcionan las ciencias, es la tarea de la teología, que Gesché con tanto acierto practicó y narró274.

\section{Antón Vergote (1921-2013): un hombre discreto y afable, un pensador poliédrico y roqueño}

"No es, como vosotros suponéis, que éstos estén borrachos ... sino que ocurre lo que había dicho el profeta Joel"275.

De forma, semejante, pero con metodología científica, procura descifrar e interpretar la conducta distorsionada, exasperada y sobreactuada de sus pacientes, para ellos mismos, y para quienes conviven con ellos,

270 González, O., "Prólogo. El sentido y la teología”, en Gesché, A., El sentido, 11.

271 En clase decía con énfasis que la insistencia sobre la omnipotencia de Dios estaba en la raíz del deísmo y del ateísmo.

272 GESCHÉ, El sentido, 20-21.

273 Ex 3,13.

274 Weinreich, H., “Teología narrativa”, en Concilium 85 (1973) 210-221; GonZÁLEZ FAus, J.I., Acceso a Jesús. Ensayos de teología narrativa, Sígueme, Salamanca 1980; ALETTI, El arte de contar, abundante bibliografía en 221-227; GolDBERG, M., Theology and Narrative, A critical Introduction, Trinity press International, Philadelphia 1991; FREY, H.W., Theology and Narrative, Selected Essays, Oxford University Press, New York-Oxford 1993; BALAGUER, V., "La teología narrative”, en Scripta Theologica 28 (1996) 89-712.

275 He 2,15.16. Los asistentes 'interpretan' el comportamiento y Pedro desmiente, aclara, explica. Los psicoanalistas, A. Vergote, intentan descifrar para comprender. Cuerpos-texto. Hermenéutica. 
porque el psicoanálisis que practica, intenta leer los códigos de las vivencias que se alojan en el inconsciente, para luego contextualizarlos y hacer que el sujeto colabore en que afloren y conviva armoniosamente con ellas. De esto y mucho más nos hablaba con verdadera unción y acierto de láser A.Vergote, el que fuera mi profesor de Psicología de la Religión, Psicología del Lenguaje Religioso y en Cursos monográficos sobre Religión y Psicoanálisis en diversas Facultades de la UCL. Firmemente anclado en la teología, la filosofía y la psicología (psicoanálisis) se mostraba con 'aisance', con soltura, en cualquiera de los tres dominios y en todos ellos simultáneamente 276 . Pero su virtud consistía en no contentarse con practicarlos yuxtapuestos -aunque impartiera cursos en tres o más Facultades- sino en hacer posible un diálogo interdisciplinar dentro de su propia persona. Lo cual daba como resultado que se nutría de esa triple afluencia, y que beneficiaba a quienes, como yo mismo, seguían sus enseñanzas. Para disfrutar de esa 'rareza', de esa capacidad insólita, se le invitaba a participar en foros y revistas de muy diversa índole 277 , también de los propios estudiantes. Desde luego no acudía al son de trompetas, ni tenía el perfil de una gran gurú sino de un trabajador analista -casi como un becario de laboratorio- que le roba muchas horas al sueño, porque cree en su proyecto y porque desea fervientemente poder ofrecer un puñado de hipótesis, con que andar por casa, por las 'casas de los espíritus' y las desasosegadas por tantos ruidos, también piadosos. Nunca defraudaba. Siempre estaba a la altura de las expectativas, que se depositaban en él, y continuamente regalaba alguna sorpresa de sus investigaciones más recientes o que traía entre manos. Pensamiento vivo en estado casi puro.

En una de sus obras, muy significativa para el tema que nos ocupa aquí, Interprétatión du langage religieux (1974), dice: "Los textos que componen esta obra son en conjunto una hermenéutica de la existencia y una lectura del discurso cristiano. Y la hermenéutica de lo humano se

276 De su copiosa bibliografía destacamos: Vergote, A., Psicología religiosa, Taurus, Madrid 1967; Id., Religión, foi, incroyance. Étude psychologique, Pierre Madarga, Bruxelles, 1987; 'Amarás al Señor tu Dios'. La identidad cristiana, Sal Terrae, Santander, 1999; Modernidad y cristianismo, PPC, Madrid, 2002; Moderniteit en Christendom. Gesprek in vrijheid en respect, 1999; Id., "Le nom du Père et l'écart de la topographie symbolique", en CASTElli (ed.,), L’Analyse; Id., La Eucaristía, símbolo y realidad, Studium, Madrid, 1973 (su original en francés 1970); "Aportación de los datos psicoanalíticos a la exégesis. Vida, ley y escisión del yo en la epístola a los Romanos 7", en Varios, Exégesis y hermenéutica, 88-122, seguido de un debate en mesa redonda, 123-138.

277 ZIEBERTZ, H.G. (ed), Imagining God. Empirical Explorations from Internationale Perspective, LIT Verlag, Münster 2002. 
continúa según los tres objetivos del pensamiento actual: ascensión hacia la dimensión mítica de todo lenguaje, el desciframiento de las articulaciones inconscientes de la existencia y la reflexión sobre la interlocución constitutiva de la subjetividad"278. Añade que únicamente una teología, que tome conciencia explícita de ello, será capaz de "retomar su lenguaje en su fuente y de regenerar su poder de comunicación". Lo cual no supone que deba plegarse a las exigencias del discurso humano y que renuncie a lo que le es propio: presentar el misterio de salvación que Dios cumple en Jesucristo. Vergote no rebajaba las exigencias de sus planteamientos para hacerlos más aceptables, al contrario, se expresa con rotundidad pero con 'libertad y respeto', con parrhesía ${ }^{279}$.

Como buen psicoanalista sabía, que es en el lenguaje donde en gran medida, se juega la partida del discurso sobre Dios; y como hacía también A. Gesché, al proponer una cierta conversión de la teología hacia la antropología, A.Vergote defiende que "son las palabras sobre Dios las que hacen que Dios se convierta en Dios-para-el-hombre"280. En efecto, para que el ser humano sea capaz de ser un buen interlocutor de Dios, debe apercibirse previamente de lo que Vergote llama "el poder de la palabra y la dialéctica del deseo". En definitiva, del entramado que compone su propia persona y la realidad que le circunda: "los discursos míticos, la subjetividad deseante, la estructura simbólica de la relación familiar, el espesor imaginario de la patología, la emergencia en primera persona en la interlocución"281, entre otras cosas.

Por tanto, Vergote propone, sobre todo cuando ejerce como psicoanalista, sanar la palabra, 'deconstruir para regenerar' y remontarse a lo que él llama 'la arqueología rememorativa' para averiguar, en la historia de la fe del creyente y de la propia teología, las fisuras y tropiezos a partir de los cuales han ido apareciendo los desequilibrios y los desencuentros, hacerse cargo del enfermo mental o del tenido por tal, como le sucedió al propio Jesús 282 . Los análisis llevan consigo, evidentemente, diagnosis y prognosis, interpretar síntomas y proponer correcciones. Hermenéutica. Lo cual conduce necesariamente a contextualizar y a historiar

278 Vergote, A., Interprétation du langage religieux, Seuil, Paris 1974, 7.

279 VERGOTE, Moderniteit, 39.

280 Vergote, Interprétation, 8. He ahí la importancia de un lenguaje adecuado de Dios y sobre Dios -en realidad, del-hombre-sobre- Dios- en la catequesis, la liturgia, las traducciones de la Biblia como he señalado más arriba. Condiciona en gran medida la recepción, la 'apropiación comprensiva' - y la participación para la comunión.

281 Ibid., 9.

282 Mc 3,21. 
el relato de la persona o personas analizadas, para explicitar lo implícito y, como por el hilo de Ariadna, salir del laberinto. Esto, que vale para el discurso en general, halla una aplicación muy pertinente cuando se trata del discurso religioso. En ello se ocupó a fondo y con gran destreza A. Vergote, poniendo a disposición de su lectura de lo anómalo sus muchos registros y su pluridisciplinaridad. El resultado a esperar del esfuerzo, por lo que a fe concierne, era la posibilidad de acceder a un ámbito más rico de sentido 283 . Es un hecho fácilmente constatable que el hombre no dispone completamente de su sí mismo, de sus 'propias verdades'; que su pensar y su sentir están poblados de una serie de símbolos, que necesita desentrañar y comprender para comprenderse; que su estar en el mundo también necesita esa 'hermenéutica vital'. Sólo así sabrá quién es y qué pinta en la vida. Por tanto, y es una de las aportaciones que le son propias a Vergote, el discurso religioso debe también echar mano de la ayuda, que le brinda el psicoanálisis. Más que resultados concretos en sus pesquisas lo que ofrece es que facilitan, como él mismo admite, la toma de conciencia de que una hermenéutica guiada por el psicoanálisis "ayuda a restaurar la conveniencia entre las palabras y lo que dicen" 284 . Defiende que en el intercambio entre teología y psicoanálisis no caben ni abordajes, ni asimilaciones, ni choques frontales. Ninguno de los dos necesita el aval del otro. Cada uno de ellos, dice Vergote, tiene bien ganada su credibilidad. Cuando proyectan su mirada y aplican sus métodos al discurso religioso, constatan que éste "únicamente se impone por sí mismo para aquellos que habitan junto a él. Sin embargo la existencia concreta del creyente es el lugar de sus intercambios" 285 . No obstante es consciente de la desconfianza, infundada según él, entre Psicoanálisis y Exégesis, que no debería ser óbice para un mutuo enriquecimiento ${ }^{286}$. El riesgo en la confrontación es real pero también la ganancia en comprensión: "la información psicoanalítica nos obliga a apartar las hipótesis hermenéuticas que no dan razón satisfactoria del texto"287.

En la misma dirección se expresa la Comisión Pontificia sobre lo que cabe esperar del psicoanálisis para la exégesis. Reconoce que la psicología y la teología han mantenido un diálogo constante a través del tiempo. Afirma que tanto la psicología como el psicoanálisis se esfuerzan por colaborar en el conocimiento de la experiencia religiosa, que en el

283 VERGOTE, Interprétation, 17.

284 Ibid., 18.

285 Ibid., 19.

286 Ibid., 88.

287 Ibid., 121. 
campo de la exégesis "abren el camino a una comprensión pluridimensional de la Escritura, y ayudan a decodificar el lenguaje humano de la Revelación"288; que han aportado "una nueva comprensión del símbolo" muy útil para comprender mejor el sentido de los ritos del culto, de los sacrificios, de las prohibiciones, para "explicar el lenguaje bíblico". No obstante, es preciso mantener un diálogo crítico y "respetar las fronteras de cada disciplina". En cualquier caso, la competencia de A. Vergote, al aunar en sí la maestría en teología dogmática, filosofía, psicología y psicoanálisis, le convierte en un interlocutor muy válido para los temas que he comentado, en un referente imprescindible de hermenéutica vital.

\section{Conclusión}

"El pasado cristiano ha permanecido siempre claramente consciente de la inaccesibilidad de Dios y de su inefabilidad, así como también de la radical incapacidad del hombre para hablar de manera suficiente acerca de Dios y para representárselo"289. Las cosas no se han aclarado en el presente, incluso se han agravado, aunque el grado de comprensión de la realidad en su conjunto haya experimentado un salto cualitativo respecto a épocas anteriores de la historia, porque hoy somos más conscientes que entonces de que es inadecuado "incluso nuestro actual 'silencio acerca de Dios" 290 . Es decir, estamos ante una guerra sin cuartel, incluso nuestro silencio podría ser interpretado como cómplice de la desidia, del abandono, de la rendición, del desacato. Hay que seguir intentándolo. Algo hemos ganado, al menos provisionalmente, con el progreso de las ciencias: contar con que el modo de existir propio del ser humano es comprender comprendiéndose. Por tanto "podremos únicamente hablar con sentido acerca de Dios, cuando ese enunciado esté vinculado con la comprensión humana de sí mismo" 291 . Como ésta crece y se profundiza con el paso del tiempo, en la misma proporción debe hacerlo nuestro modo de hablar acerca de Dios. Son dos proporciones que se corresponden. Éste

288 Pontificia Comisión Bíblica, La interpretación de la Biblia, 59. La cursiva es mía. ${ }^{289}$ SCHILlebeECKX, E., "La razón del callar acerca de Dios y del hablar de Dios y hablar a Dios", en Dios, futuro del hombre, Sígueme, Salamanca 1970, 77.

290 Ibid., 79. La cursiva es mía.

291 Ibid., 80. Precisamente en esa encrucijada se sitúa la reflexión teológica de A. Gesché, así como la de A.Vergote, P.Ricoeur, J.Ladrière, M.Legido, de quienes hemos hablado más arriba. 
ha sido el eje en torno al cual ha girado la presente colaboración, explorando algunas de las aportaciones que cabe esperar de la exégesis, y sobre todo de la hermenéutica. He insistido en que la realidad, la vida, puede ser tenida como 'texto' a descifrar; en que, cuando se trata de la Palabra de Dios, la vida de la gente buena es un lugar teológico privilegiado, para encontrarnos con ella. El desarrollo, en su conjunto, lo he presentado como una serie de variaciones sobre el tema: La COMPRENSIÓN de la PALABRa por la santidad de la VIDA, de vida, debida a la BONDAD de quien la hace posible.

Por tanto: La Palabra Se Hizo Carne ... Palabra, palabras, carne, texto, vida ... ... en la Palabra la vida ... entera ... carne ... poner en la mesa la Palabra ... en la mesa de la vida de sus manos el pan de la Palabra y el pan-su-Cuerpo y el vino-su-Sangre en la-mesa-de la-cena ... muerte presentida... anunciada ... consumada ... y luego Vida ... y luego camino ... y otra vez PALABRA ... palabras ... corazón-que-ponela-mesa y palabra en ella y vino y pan y corazón y vida ... y otra vez camino... .camino-en-la-noche como en la noche-del-paso y como en esa santa noche-del-cirio-pascual...encuentro ... y ... mesa-de-la-palabra y alegría... VIVE ... y recuerdan ... los encuentros ...y cuentan...y escriben la historia santa ... camino...diez-palabras-en-la-piedra ... subió al monte.... y dijo ... siempre el recuerdo ...el bendito recuerdo ... que cauteriza las viejas llagas .... y alivia las nuevas e interminables llagas-de-lavida poniendo VIDA en ellas.... Tú mi JERUSAlÉn ... "si me olvido de ti, Jerusalén que se me pegue la lengua al paladar que se me paralice la mano derecha" ... "¿puede una madre olvidarse del hijo que amanta? ... yo no te olvido" ... "hacedlo en memoria mia" ... vino ... pan ... carne ... sangre ... texto ... compromiso ... "QUOD SCRIPSI SCRIPSI" ...... título para la cruz ... texto duradero...escribía con el dedo en el suelo ....se borraba ... texto perdido pero texto ... ALFA y OMEGA ... alfabeto completo... "¿no tienes nada que decir?” ... callaba ... Silencio-Palabra ... Silencioen-la-mesa-de-los-ruidos ... mesa-en-el-centro-del-conflicto ... de cualquier encrucijada ... palabras-abalorio... palabras-creación... palabrasamuleto.... palabras-exorcismo.... palabras-juicio ... palabras-vida...sal fuera...no peques más ... ve a presentarte ... tus pecados están perdonados ... "effetá"...ábrete... boca ....oídos...ojos...mar rojo..."Yo soy" ... "estoy a la puerta y llamo" ... "guardareis mis palabras" .... antes ... después ... siempre ... "SOIS CARTA DE CRISTO"... palabras ... palabras ... siempre ... también al centro del universo ... de la historia ... profetas ... sobre todo la Palabra ... tal como salida de la boca del Padre llena de 
gracia y verdad .... Palabra interpretada por la carne la carne por la Palabra interpretada por la vida interpretada por la Palabra ... la Palabra ... antes ... después ...decid... no digáis muchas palabras... dijo "¿tenéis algo que comer?" ....”tomad y comed" ... "Toma y ComE" ...dijo.... quien la escucha... no todo el que dice ...dijo sal fuera...dijo..."ven y sígueme"...dijo ... "el que escucha esta palabras mías y no las pone en práctica se parece a" .... "el que las escucha y las pone en práctica .... se parece a" ....dijo "y yo te digo"...dijo ... "si he hablado mal"....dijo... "tengo sed"...dijo..."dame de beber"... "tomad y bebed"... dijo ... "hoy estarás conmigo" ... "no todo el que dice Señor"... dirá ... "venid benditos" ... "alejaos de mí malditos" dirá ... sangre de la Palabra ... del pan.... "no sólo de pan... sino de toda Palabra que sale de la boca de Dios"... la Palabra ... del Silencio ... el Hijo ... la Palabra hecha carne en las palabras ... testimonio ... carne crucificada ... resurrección de la carne... Alfa y Omega ... de toda raza, nación y lengua ... LIBRo DE LA VIDA ... carne-texto ... ... carne testificada.... MARTIRIO ... carne textificada... ESCRITURA interpretada ... HERMENÉUTICA de la bondad ... reflejo-deDios-que sale-al-encuentro-del-hombre... “iescuchadle!”.... 